\title{
WASTER
}

ORNL-4677

UC-35 - Nuclear Explosions -

Peaceful Applicotions

RADIOACTIE CONTAMINATION OF

COPPER RECOVERED FROM ORE FRACTURED

WITH NUCLEAR EXPLOSIONS

W. D. Arnold

D. J. Crovie

THIS DOCUMENT CONFINUTE AS UnCLASSHEn DIVISION OF CLASSITCATION

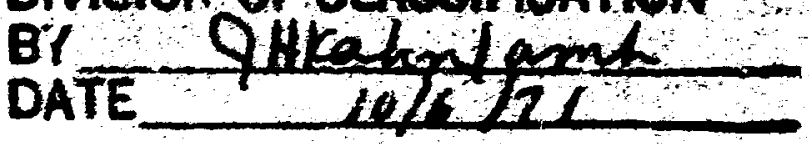

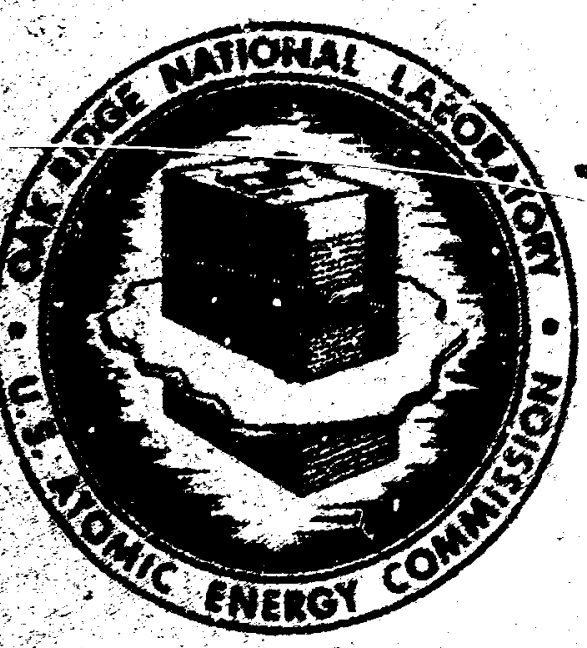

oAK RIDeE national laconatony oporated by

UNION CARAIDE CORPORATION

lot the

11. S. ATOMIC ENECY COMMISSION 
BLANK PAGE 


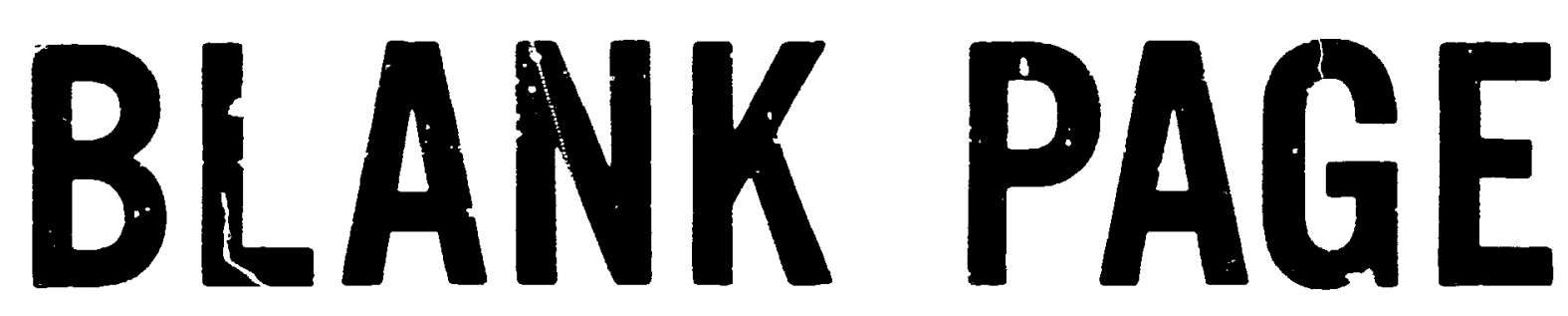


Contract Fo. H-7405-eng-26

CHAMTCAI: TIE WIIOLOGY ITIVISIOT

RADICACTIVE CONTAYTIATION OF COPFER RECOVERED FROA ORE FRACTURED WITH IUUIBAR EXPLOSIVES

W. D. Arnold

D. J. Crouse

\section{SEPTEMBER 1971}

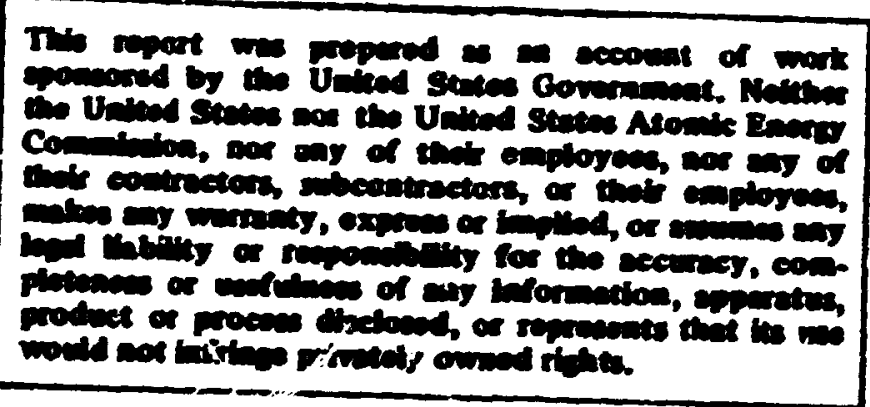

OAK RIDGE MATIORAL IABORATORY

Oak Ridge, Tennessee

operated by

UNION CARPIDE CORPORATION

for the

U.S. ATONIC EIUGHY COMISSION 
Abstract $\ldots \ldots \ldots \ldots \ldots \ldots \ldots \ldots \ldots \ldots \ldots \ldots \ldots \ldots \ldots \ldots \ldots \ldots \ldots \ldots \ldots \ldots \ldots \ldots 1$

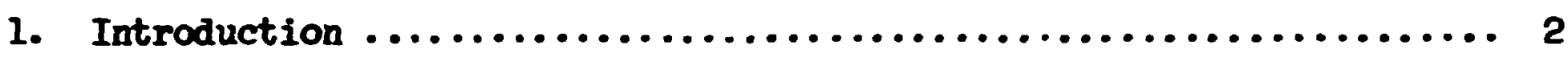

2. Radiomaclides Present ............................... 4

3. Process Flarsheet $\ldots \ldots \ldots \ldots \ldots \ldots \ldots \ldots \ldots \ldots \ldots \ldots \ldots \ldots \ldots \ldots \ldots \ldots \ldots$

4. Leaching of Radioactive Debris $\ldots \ldots \ldots \ldots \ldots \ldots \ldots \ldots \ldots \ldots \ldots \ldots$

4.1 Adsorption of Radionuclides by Coprer ore .............. 10

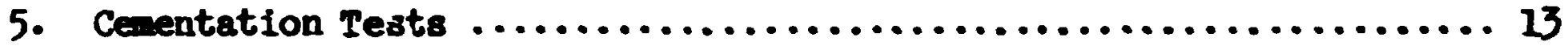

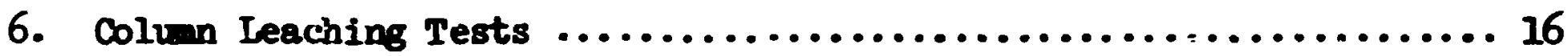

6.1 Tritiu $\ldots \ldots \ldots \ldots \ldots \ldots \ldots \ldots \ldots \ldots \ldots \ldots \ldots \ldots \ldots \ldots \ldots \ldots \ldots \ldots \ldots \ldots$

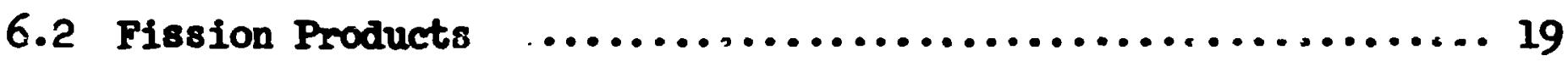

6.3 Activation Products $\ldots \ldots \ldots \ldots \ldots \ldots \ldots \ldots \ldots \ldots \ldots \ldots \ldots \ldots$

7. Purification of cenent copper $\ldots \ldots \ldots \ldots \ldots \ldots \ldots \ldots \ldots \ldots \ldots \ldots \ldots \ldots$

7.1 Kelting and Ilectrolysis $\ldots \ldots \ldots \ldots \ldots \ldots \ldots \ldots \ldots \ldots \ldots \ldots$

7.2 Dissolution and Eiectrorinning $\ldots \ldots \ldots \ldots \ldots \ldots \ldots \ldots \ldots \ldots$

7.3 Control of ${ }^{106}$ Ru $\ldots \ldots \ldots \ldots \ldots \ldots \ldots \ldots \ldots \ldots \ldots \ldots \ldots \ldots$

8. Solr nt Extraction of Copper $\ldots \ldots \ldots \ldots \ldots \ldots \ldots \ldots \ldots \ldots \ldots \ldots \ldots \ldots$

8.1 Batch Extraction Tests ............................... 31

8.2 Demonstration of Colun Ieaching--Solvent Butraction-Electrorinning Flowsheet ......................... 34

9. Process Evaluation $\ldots \ldots \ldots \ldots \ldots \ldots \ldots \ldots \ldots \ldots \ldots \ldots \ldots \ldots \ldots \ldots \ldots \ldots$

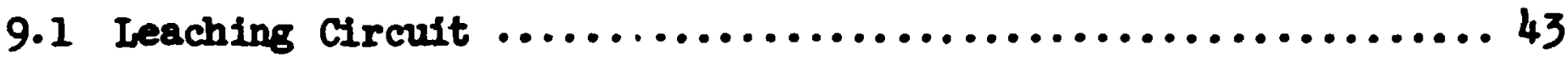

9.2 Cementation--Anode Casting--Electrolysis Flowsheet ........ 47

9.3 Solvent Extraction--Electrowinning Flowsheet ........... 49

9.4 Wuste Dlsposel ............................... 50

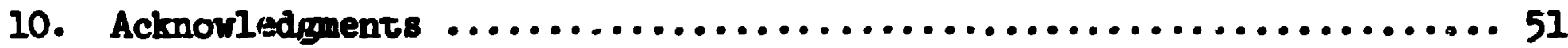

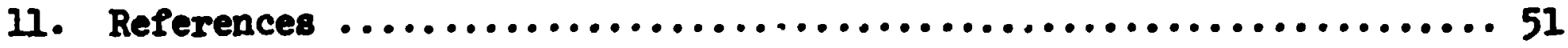


RADIOACTIVE CONFAMIMAT TOR OF COPPER RECOVERED

FROY ORE FRACTURED WITH NUCLEAR EXPLOSTVES

W. D. Arnold

D. J. Crouse

\begin{abstract}
Results 0:: laboratory tests simulating the processing of copper ore after fracturing with nuclear explosives indicate that only very small fractions of the radioactive fission products and neutron activation products will be dissolved on leaching with sulfuric acid. Tritium (as tritiated water) will be, by far, the dominant radionuclide in the circulating leach liquor, assuming use of a fusion device.

Copper that was recovered from the leach solution by cementation ras significantly contaminated with ${ }^{106} \mathrm{Ru}$. The ${ }^{106} \mathrm{Ru}$ was rejected efrectively in electrolytic purification; therefore, the final copper product should be very weakly rajioactive and not hazardous to the customer. However, the radioactiviti level may be high enough to make the copper unsuitable for some specific uses. Tise tritiated water in the lesch liquor and the ${ }^{108} \mathrm{Ru}$ in the cement copper are potential problems at the plant site and should be carefully consilered in the design and in the operation of the facility. However, since the racloactivity levels would be low, adequate protection for the operating personnel should be neither diffscult nor costly to prowide.

Results of orr tests showed that the use of solvent extraction as an alternative to cementat ion for recovering copper from the leach liquor would have important advantages. Since copper is efficiently separated from radionuclides in the extraction step, radioactivity in the processing operations beyond the extraction contactors should be negligible. The radicactivity level of the final copper product recovered from the solvent extraction strip solution by electrowinning should be almost undetectable; therefore, marketing of the copper should not present any difficulties. Becauso of the superior marketability of the product and the much simpler radiation control problems at the processing site, use of the solvent extraction--electrowinning flowsheet is recommended.
\end{abstract}





\section{THIRODUCTIOI}

The fracturing of copper-bearing ore bodies with nuclear explosives, vith subsequent leaching of the copper from the ore in place, has been proposed as a potential low-cost method for recovering copper from deep deposits that cannot be mined economically in the usual manner. The technical and economical feasibility of this proposal has been examined over a period of years by the Division of Peaceful Nuclear Explosives of the U.S. Atomic Energy conission in cooperation with associated contractors and with the Kennecott Copper Corporation. An experiment (Project Slop) was designed to field test the application in a deep low-grade copper ore deposit orned by Kennecott near Safford, Arizona. ${ }^{1,3}$ The Chemical Technology Division of the Oak Ridge National Laboratory has cooperated in this program by evaluating potential problems that might arise from the presence of radioactive contaminants in the processing cycle.

The nuclear detonation would create a chimney, several hundred feet high and approximately cylindrical in shape, containing several million tons of ore rubble. The recovery florsheet involves percolating dilute sulfuric acid down through the broken ore to disesive tine sopper, collecting the leach iiquor at the bottom of the chimney and pumping it to the surface, recovering a copper concentrate from the solution by presipitation (cenentation) or solvent extraction, upgraaing the concentrate to pure copper metal, and recycling the copper-barren solutior to the leaching ster after fortifying it with acid 'Fig. 1).

We have grouped the potentisl problems arising from the presence of radionuclides in the system under three main categories: (1) evaluation of radiation hazards to operating personnel in the processing complex; (2) possible radiocontamination of the copper product, which, of course, could affect its marketability; and (3) potential radiation hazards to the general public, which would arise from disposal of process wastes or from underground migration of radionuclides to the off-site environment. The last is outside the scope of the present studies but has been considered by Stead and others. 3,4

This report is the final summary of studies mede at ORIL in relation to this program. It includes information that was reported previousiy at 
Coven ons $n-140$

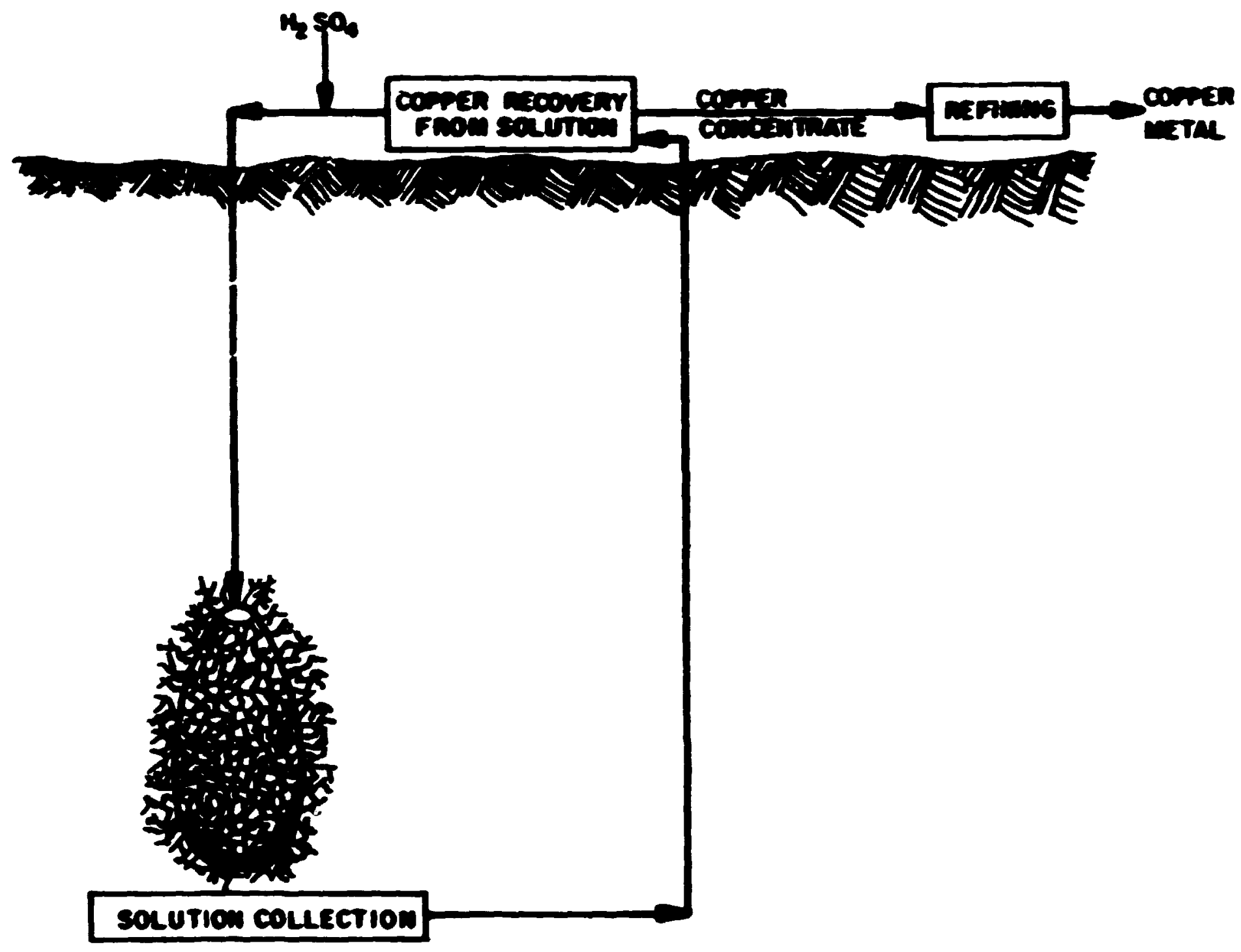

Fig. 1. Copper Recovery by In-Situ Leaching of Copper Ore broken by Use of a Tuclear Device. 
a Plowshare Symposium and, in more detail, in our quarterly progress remonts. In this report, an estimate is made of the suounts of the different radionuclides that wouli be present in tine broken rock, their leachability under expected flowsheet conditions, and their behavior in processira steps such as copper cementation, solvent extraction, and electrolytic mirification of copper. Finally; an assessment is made of potential hazards frow radionuclides at the processing site and of the suitability of the copper products.

\section{RADIORUCLIDES PRESETYT}

The quantities of tritiun and each of the fission products produced by a. detonation of a given yield depend, of course, on the type of device used. Figure 2 gives 2 rough estimate of the gmounts of tritium and the more important fission products as a function of time following an arbitrarily assumed 50-kiloton shot in which $90 \%$ of the enerEy is derived from fusion and $10 \%$ from plutonium f:ssion. The estinated production of 2,5,000 $\mathrm{Ci}$ of tritium per kiloton of fusion is the approximate midpcint of the range specified by Miskel (i.e., 7000 to $50,000 \mathrm{Ci} / \mathrm{kiloton}$ ). Isotopes

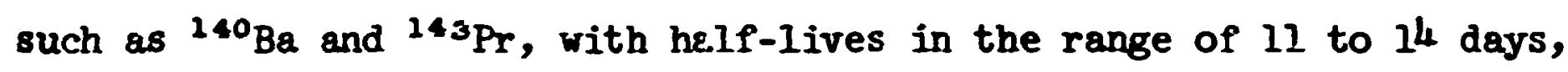
would be present in large amounts shortly after the detonation but would essentially disappear before the start of leaching at about 300 days. other isotopes such as ${ }^{103} \mathrm{Ru},{ }^{91} \mathrm{Y}$, and ${ }^{95} \mathrm{Zr}-{ }^{96} \mathrm{Nb}$, with half-lives of intermediate range, would be present in significant amounts at the start of leaching but would rapidly diminish in importance over the 1 - to 2 -year perind of ieaching. This woüla leeve ${ }^{106 \mathrm{ph},}{ }^{147} \mathrm{fm},{ }^{i 44} \mathrm{Ce},{ }^{137} \mathrm{Cs},{ }^{90} \mathrm{Sr}$, and ${ }^{125} \mathrm{Sb}$ as the most significant fission products in the chimney during the time of processing. At 300 days, the activity of the tritium would be more than an order of magnitude greater than the total fission product actfivities. Choice of an all-i'ission device woul?, of course, greatly increase the relative importance of the fission products is compared with tritium.

Previous Plowshare experience with contained underground nuclear explosions has shown that rost of the fission products are trapped fairly efficiently in the melted rock that accumulates at the bcttom if the ore 


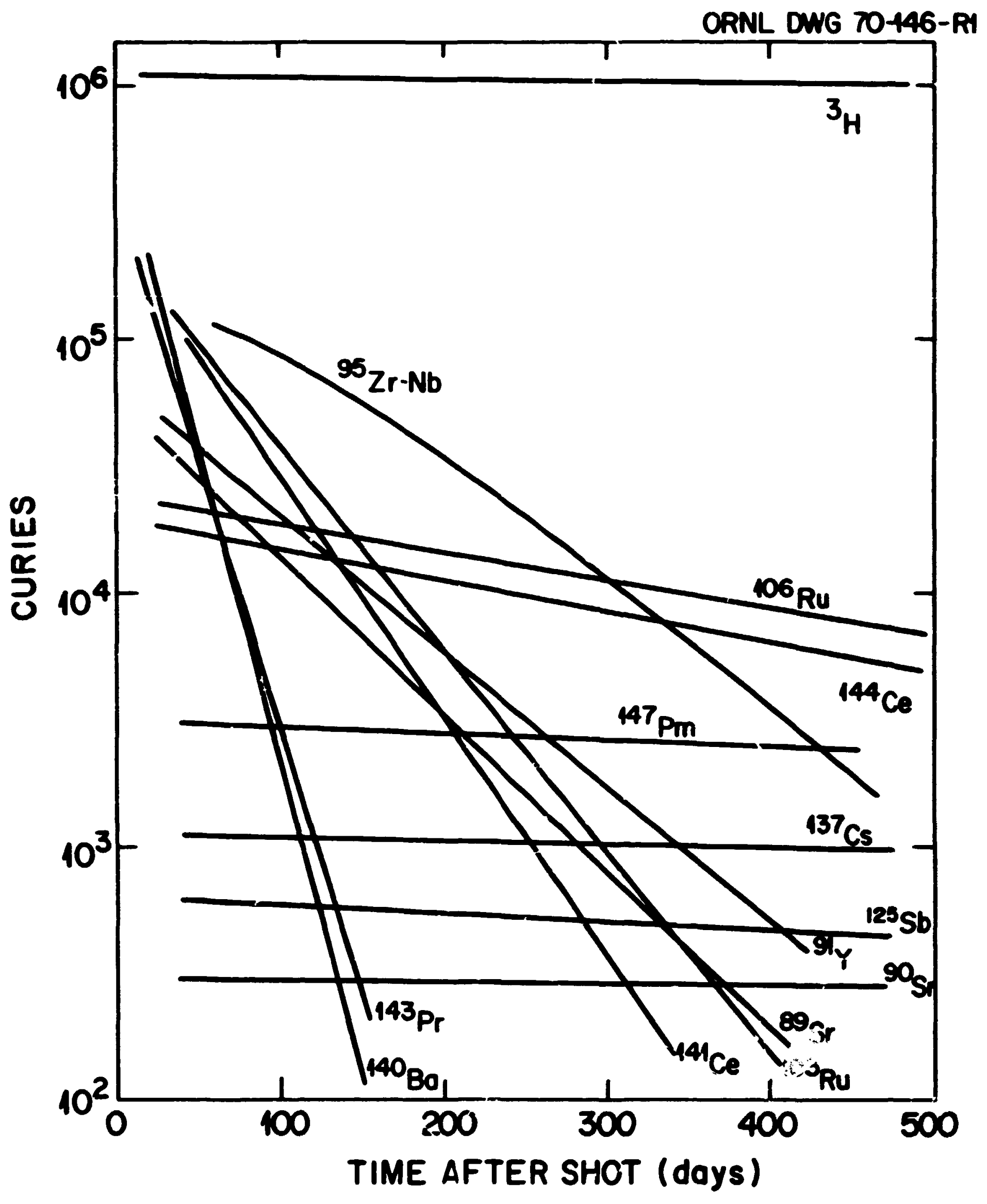

Fig. 2. Estimated Amounts of Radioactive Fission Products and Tritium Resulting from a 50-xiloton Shot (90\% Fusion--10\% Plutonium F1ssion). 
chimney. Tnis fused material is not very leachable. However, appreciable anounts of certain fission products, for exemple, ${ }^{137} \mathrm{Cs}$ and ${ }^{90} \mathrm{Sr}$ (which have gaseous precursors) and ${ }^{306} \mathrm{Ru}$ and ${ }^{125} \mathrm{Sb}$ (which form voletile compounds), wove up into the chimney and deposit on the ore rubhle in a more leachable form. The tritium should be present as tritiated water and, therefore, in a completely soluble form.

In addition to the fission products and tritiun, ridionuclides that are formed by neutron activation of the device components and of the surrounding ore will be present. The quantities of the radionuclides that are produced depend on the composition of the ore and on certain conditions of the experiment. The principal induced radionuclides present in an ore sample from the Safford deposit after irradiation in the Oak Ridge Research Reactor and a cooling period of 300 days vere ${ }^{46} \mathrm{Sc},{ }^{60} \mathrm{Co}$,

${ }^{64} \mathrm{Kn}$, and ${ }^{65} \mathrm{Zn}$ (see Sect. 6.3). Since most of the released neutrons would be captured in the immediate vicinity of the detonation, the bulk of the activation products would be contained in the glassy melt and should be in a relatively unleachable form. ${ }^{\circ}$

\section{PROCESS FLONSHEET}

The original process flowsheet (i.e., the flowsheet considered for Project Sloop) involves recovery of a copper concentrate from the leact: liquor by cementation on scrap iron (Fig. 3). The cenent copper from this operation would be melted into consumable anodes ard purified by electrolysis before being marketed as copper metal. Most of our studies of the behavior of radionuclides were made assuning use of this flowsheet. Over the period of the studies, a new suivent extraction process9.10 was developed in industry as an alternative to cenentation, and this process is obtaining rapid acceptance in copper ore processing. our stuaies have indicated that the 30 ivent extraction route (Fig. 3) provides a much more efficient separation of copper from the radionuclides than does the cementation route, and entails fewer personnel radiation protection problems at the processing site. For these reasons, solvent extraction appears to be the best process for use when muclear explosives are employed in copper recovery. 
ORNL OWO 71-148

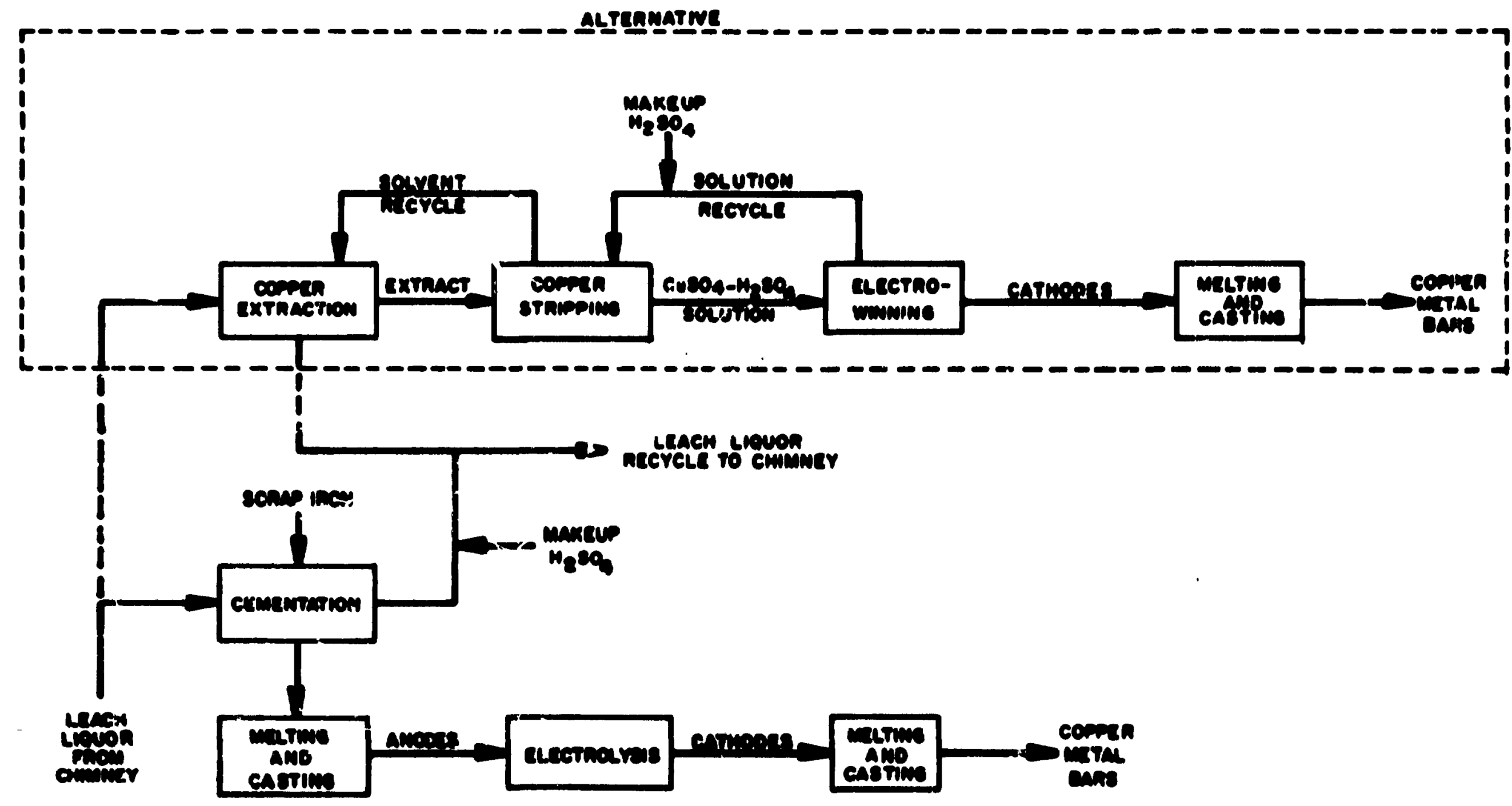

Fig. 3. Cementation-Electrolyo1s and solvent Extraction--

Electrowinning Flmwheets for Copper Recovery. 


\section{IEACRING OF RADIOACTIVE DEBRIS}

Because copper ore that had been broken by nuclear explosives was not available for leaching tests, we studied the leaching of radionuclides from debris samples that were recovered from two underground test shots at the Hevada Test Site. Radiochenical analyses of these samples are giren in Tabie 1. The samples were leached for several days at rocm temperature in the $\mathrm{pH}$ range of 1 to 3.5. Sulfuric acid was added during the leaching step to maintain the $\mathrm{pH}$ at the desired level.

The debris from test shot 1 was in the form of puddle glass (fused rock) and rubble frow the bottom of the chimney. Under the expected flowsheet leaching conditions ( $\mathrm{pH} 2$ to 3 ), less than $2 \%$ of any of the longlived radiomaclides were dissolved from the pudale glass (FIg. 4). However,

Table 1. Radiochenical Analysis of Test Shot Debris

Test shot 1: puddle glass and rubble from the bottco of the chimney; about 3-1/2 years old.

Test shot 2: sampied about $200 \mathrm{ft}$ above the shot point; about 2 years oid.

\begin{tabular}{|c|c|c|c|}
\hline \multirow[b]{3}{*}{ Radic aucljde } & \multicolumn{3}{|c|}{ Concentration (dis $\min ^{-1} \mathrm{~g}^{-1} \times 10^{4}$ ) } \\
\hline & \multicolumn{2}{|c|}{ Test Shot 1} & \multirow{2}{*}{$\frac{\text { Test Shot } 2}{\text { Rubble }}$} \\
\hline & Puddle Glass & Rubble & \\
\hline${ }^{137} \mathrm{Cs}$ & 1.4 & 2.2 & 2.1 \\
\hline${ }^{144} \mathrm{Ce}$ & 2.2 & $0.0_{4}$ & $<0.03$ \\
\hline${ }^{90} \mathrm{Sr}$ & 4.1 & 0.09 & 0.2 \\
\hline${ }^{108} \mathrm{Ru}$ & 2.0 & 0.12 & 1.4 \\
\hline${ }^{60} \mathrm{Co}$ & 3.7 & 0.01 & $\mathbf{a}$ \\
\hline${ }^{125} \mathrm{Sb}$ & $\mathbf{a}$ & $\mathbf{a}$ & 0.4 \\
\hline Gross Genna & $2.6^{b}$ & $0.23^{b}$ & $1.0^{b}$ \\
\hline
\end{tabular}




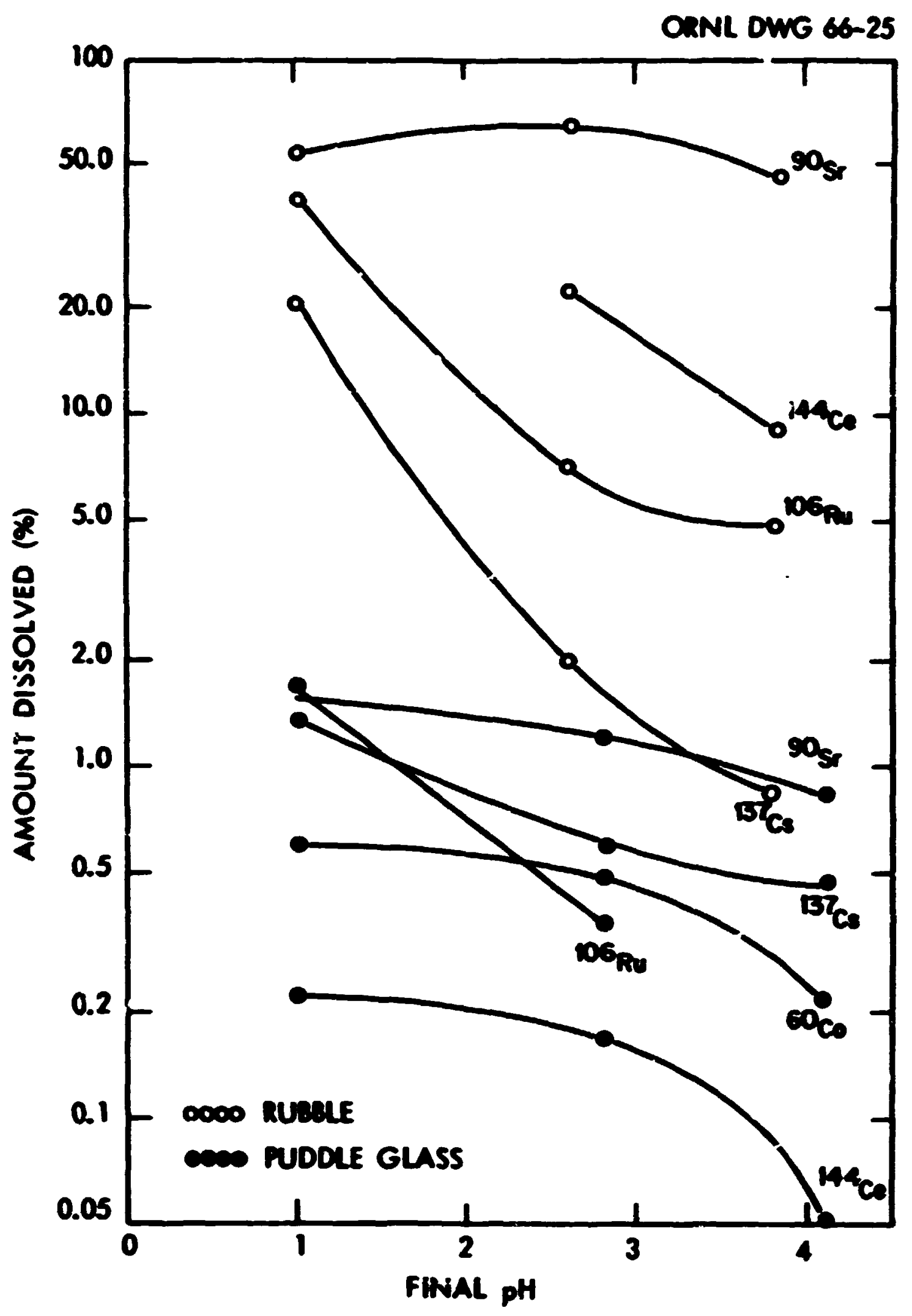

Pig. 4. Ieaching of Test Shot Debris with Sulfuric Acid.

Procedure: 10-8 samples of nimus 4-mesh debris (test shot 1, amalyses in Table 1) leached for two days at room teperature with $20 \mathrm{ml}$ or dilute $\mathrm{H}_{2} \mathrm{SO}_{4}$; acid added during leaching to malntatn the pH approximately constant at $1.0,2.5$, or 4 . The supernate was analyzed for the various radionuclides. 
about $50 \%$ of the ${ }^{90} \mathrm{Sr}$, about $20 \%$ of the ${ }^{144} \mathrm{Ce}$, and 5 to $20 \%$ of the ${ }^{108} \mathrm{Ru}$ were dissolved in this $\mathrm{pH}$ range from the ore rubble, which was sempled in the vicinity of the nelted rock. These debris semples were about $3-1 / 2$ years old at the tine cr leaching and thus did not contain detectable anounts of sone radioisotopes, for exaryle, ${ }^{95} \mathrm{Zr}-{ }^{95} \mathrm{lib}$, that would be presen at the time of copper recovery.

The second debris semple, which was taken about 200 ft above the shot point, was approxinately 2 years old. The principal radionuclides in this sample vere ${ }^{308} \mathrm{Pu}$ and ${ }^{137} \mathrm{Cs}$; smaller colcentrations of ${ }^{128} \mathrm{Sb}$ and ${ }^{90} \mathrm{Sr}$ were 2180 present. About $50 \%$ of the ${ }^{90} \mathrm{Sr}$ and 30 to $35 \%$ of the ${ }^{109}$ ind were dissolved in the pH range of 1 to 2 (Pig. 5). The anounts of ${ }^{125} \mathrm{Sb}$ and ${ }^{137} \mathrm{Cs}$ that were leached decreased from aout $12 \%$ at pH 1 to $4 \%$ and $2 \%$, respectively, at $\mathrm{pH} 2$. In the test at $\mathrm{pH} 3.6$, the gross genas activity of the leach solution was only 16 of that obtained at $\mathrm{pH} I$ and was too $10 \mathrm{r}$ to pernit analyses for the individual radionuclides.

\section{I Adsorption of Radionuclides by Copper Ore}

The ion exchange properties of the copper ore would be highly important in regulating the quantities of certain radionuclides that would be dissolved and carried to the surface processing operation. Batch distribution tests with soluble radiomalides showed that sone are adsorbed very strongly by the ore fram acid leach solutions (Fig. 6). In these tests, soluble radioisotopes were added to a copper ore leach IIquor that was adjusted to various $\mathrm{pH}$ levels and the solutions yeze then contacted with Safford ore lesch tailings. Certain of the 1188 ion products such as ${ }^{137} \mathrm{Cs},{ }^{95} \mathrm{Zr}-{ }^{98} \mathrm{lib}$, and ${ }^{126} \mathrm{Sb}$ and certsin potential activation products such as tungsten and silver were adsorbed strongly, with distribution coefficient ( $K_{D}=$ counts per grem of ore, divided by counts per milliliter of solution) values of 10 or higher. Strontiu was adsorbed much less readily, although still to a significant degree. The $K_{D}$ values were less than 0.25 (<4\% adsorption) for a muber of elenents including $\mathrm{Ru}, \mathrm{Fe}, \mathrm{Eu}, \mathrm{Sc}, \mathrm{Y}, \mathrm{Cr}, \mathrm{C}, \mathrm{Zn}$, and $\mathrm{Cd}$.

In other adsorption tests (results not shown) with Safford ore tailings and with solutions prepared by leaching radioactive debris, cesium adsorption coefficients were high and ruthenium and strontiv adsorption 


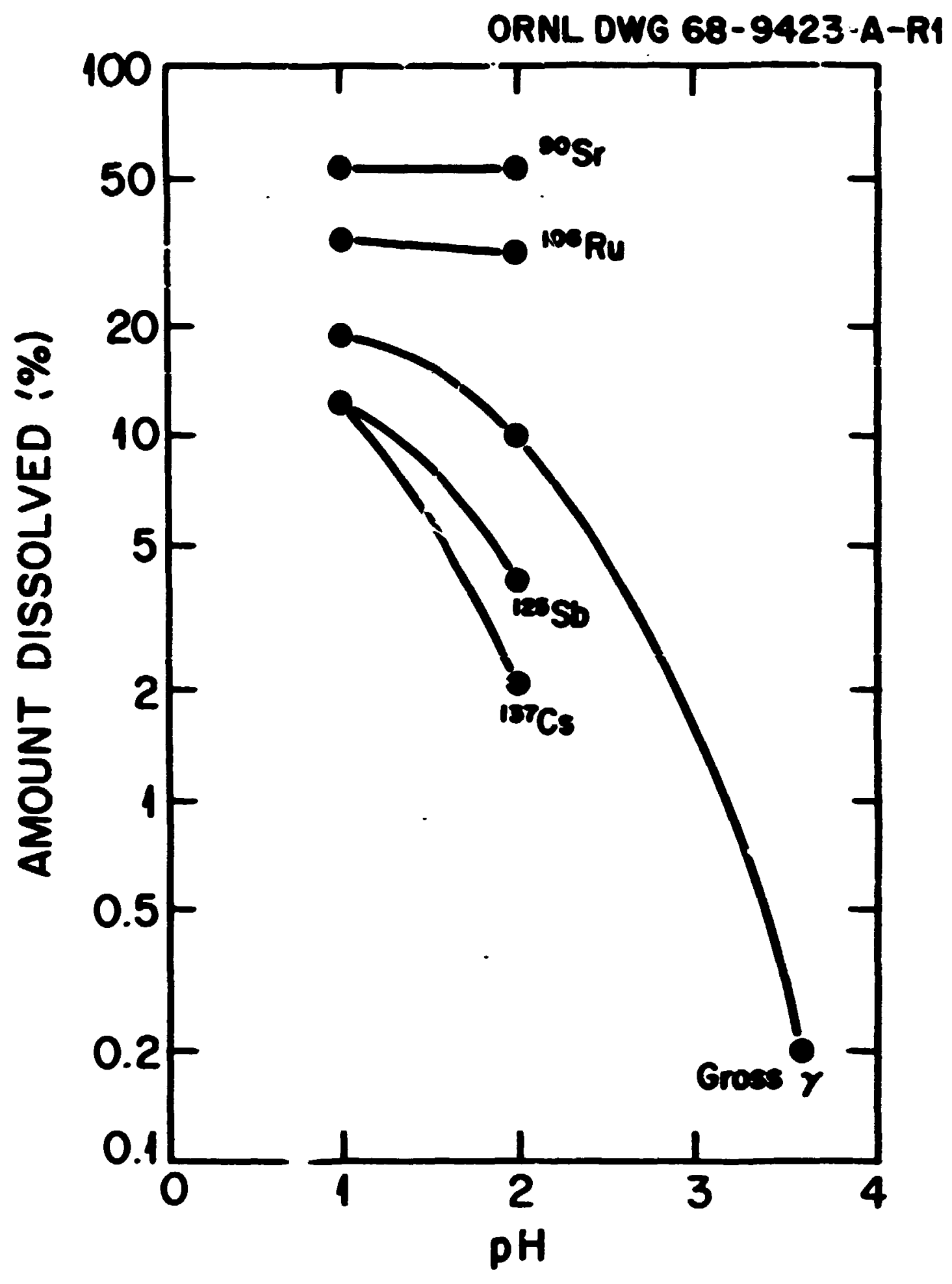

F1g. 5. Ieaching of Debris fron Test Shov 2. Procedure: 100-8 seaples of test shot debris (tent shot 2) leached 6 days with $200 \mathrm{ml}$ of synthetic copper ore leach liquor $\left(2 \mathrm{~B}\right.$ of $\mathrm{Cu}^{2+}, \mathrm{I}_{\mathrm{g}}$ of $\mathrm{Fe}^{2+}$, and $3 \mathrm{~g}$ of $\mathrm{Pe}^{2+}$ per liter as sulfates). Sulfuric acid was added during leaching to maintain the pH approxinately constant at $1.0,2.0$, or 3.6 . Anounts dissolved are based on analyses of the original aebris and the supernate. 


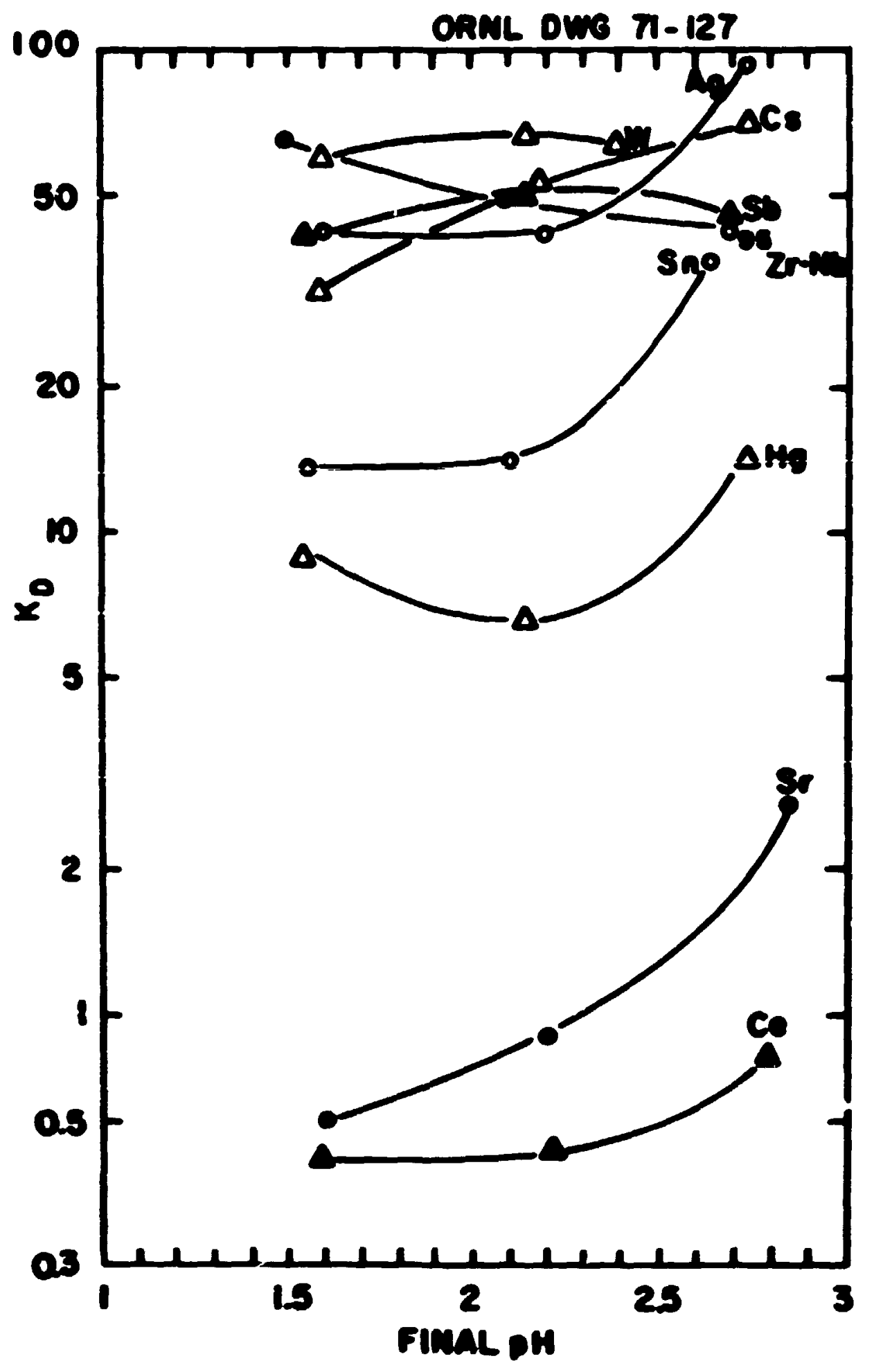

Fig. 6. Adsorption of Radiomuclides by Safford copper Ore.

Procedure: $5 \mathrm{ml}$ of Safford copper ore leach Iiquor (adjusted to different pH levels and spiked with the appropsiate radiolsotope) was contacted 16 hx with 18 of nimus 20-mesh ore tailings; anount adsorbed was calculated on the basis of analyses of the head solution and the supernate. Less than $4 / \mathrm{W}\left(K_{D}<0.25\right)$ of $\mathrm{Ru}, \mathrm{Fe}, \mathrm{Bu}, \mathrm{Sc}, \mathrm{Y}, \mathrm{Cr}, \mathrm{Co}, \mathrm{Zn}$, and cal were adsorbed in the $\mathrm{pH}$ range of 1.5 to 2.8 . 
coefificients were sinilar to those obtained by adding soluble radioisotopes to the liquor. Antimony, however, was not strongly adsorbed as before, suzgesting that the chemical form of antimony in solution was different for the two experiments.

In an actual leaching operation, the chimney of broken ore would function as an ion exchange colum several hundred feet high. Radiomuclides dissolved from the ore in the bottom of the chimney in the early phases of the leaching cycle would adsorb on the ore as the leach solution was recycled through the ore column. Even distribution coefficients considerably less than 1 would result in appreciable ion exchange retention of the radiomuclides by the ore because of the relatively large ore/solution weight ratio (possibly 10/1) that would prevail in the systen. This would be expected to linit the buildup of rediomalides in the leach liquor to concentration levels fa- below those that would be predicted on the basis of simple batch leach test results such as those shorn in Pigs. 4 and 5. sall-scale colum leachirg tests, in which soluble radionuclides were sdded to a colvm of ore, confined this behavior (see Sects. 6.2 and 8.2).

\section{CaygurHTOA TESTS}

Cementation tests were run with a simated copper ore Leach liquor to which various radioisotopes had been added. The purpose of these tests was to deternine which of these radiofsotopes night contaninate the cenent copper. As expected, the nore noble netals, such as silver, cenented alwost quantitatively with the copper (PIg. 7). Also, about 25 to $40 \%$ of the $t$ in, antinom, and ${ }^{96} \mathrm{Zr}-96 \mathrm{ho}$, and 156 of the ${ }^{106} \mathrm{Ru}$ were resored with 954 of the copper from the solution over the 90-ain cenentation period.

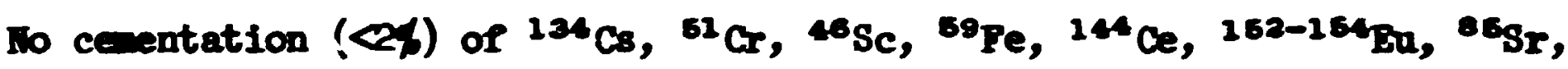
${ }^{65} \mathrm{Zn}$, or ${ }^{60} \mathrm{Co}$ was detected.

Because ${ }^{125} \mathrm{Sb}$ exhibited anonalous behaviox in sone tests, additional cenentation tests were ade with this isotope under a variety of conditions. The fraction of ${ }^{126} \mathrm{gb}$ that cenented with the copper in 60 -in tracer tests decreased from about $40 \%$ to $15 \%$ when the initial activity of ${ }^{128} \mathrm{Sb}$ in the liquor was decreased sron $10^{6} \mathrm{dis}^{\mathrm{nin}} \mathrm{n}^{-1}$ to $10^{3} \mathrm{dis} \mathrm{nin}^{-1} \mathrm{nl}^{-1}$. In teats ade with a liquor that was derived from leaching radioactive debris 


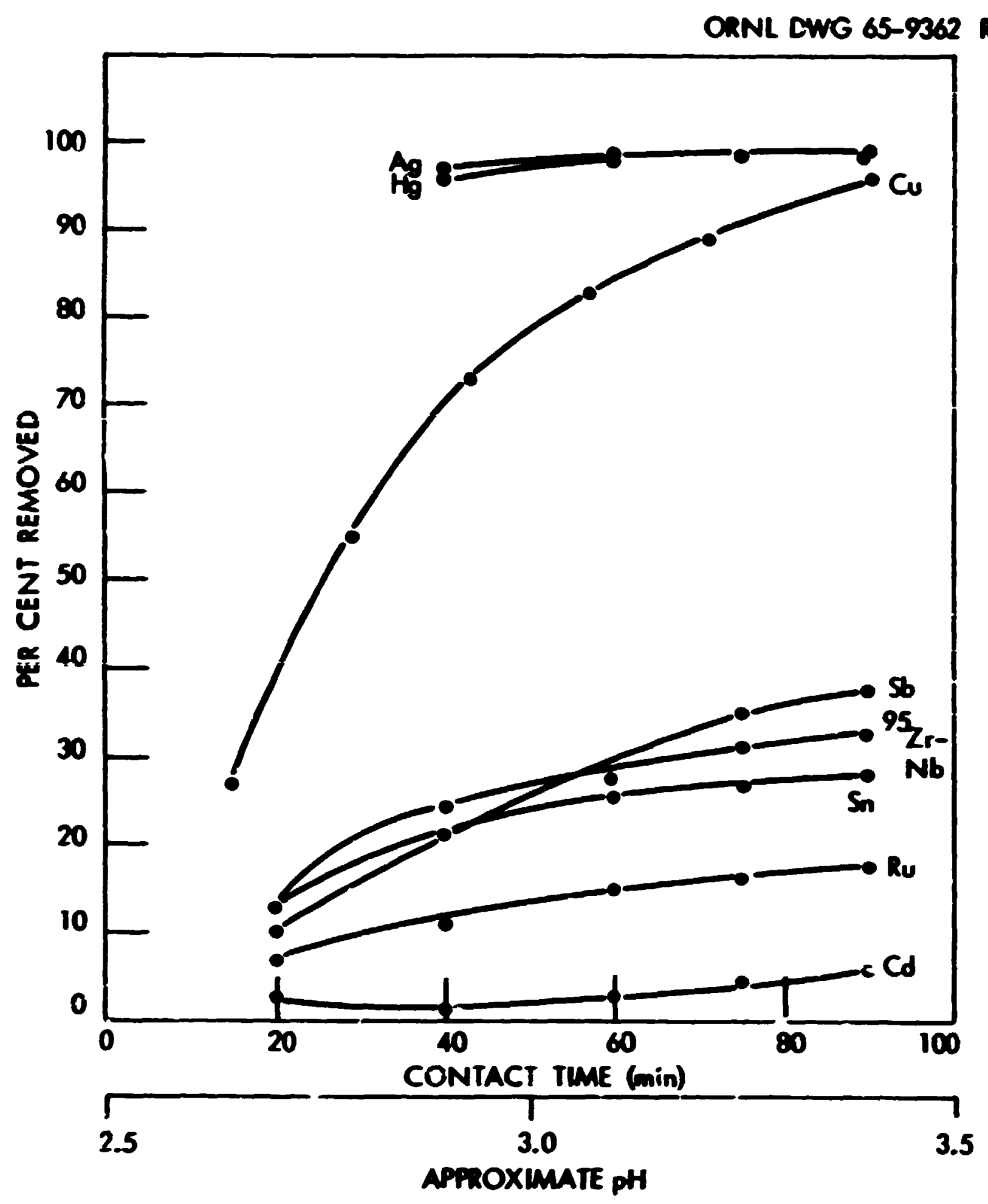

Fig. 7. Contanination of Copper Cenentation Prodict. Procedure: $200 \mathrm{ml}$ of copper ore leach liquor ( $\mathrm{g}$ of copper per liter, pH 2.5) contacted with $0.7 \mathrm{~g}$ of detinned cans for 90 min. Anount of radioisotope removed from solution was calcuiated on basis of analyses of the head solution and the supernate. Iess then 2,6 of the ${ }^{134} \mathrm{Cs},{ }^{61} \mathrm{Cr}$, ${ }^{46} \mathrm{Sc},{ }^{89} \mathrm{Fe},{ }^{144} \mathrm{Ce},{ }^{162-164} \mathrm{Bu},{ }^{85} \mathrm{Sr},{ }^{68} \mathrm{Zn}$, and ${ }^{60} \mathrm{C}$ were remorea with the copper. 
and had an ${ }^{128} \mathrm{Sb}$ activity level of only 70 dis min ${ }^{-1} \mathrm{nl}^{-1}$, no cenentation of ${ }^{235} \mathrm{Sb}(<\%)$ was detected (Table 2 ). As in the tracer tests, chere was no significant cenentation of ${ }^{90} \mathrm{Sr}$ or ${ }^{137} \mathrm{Cs}$. The amounts of ${ }^{108} \mathrm{Ku}$ cenented were $14 \%$ at $\mathrm{pH} 1$ and $8 \%$ at $\mathrm{pH} 2$; these results $\mathrm{fall}$ within the range of 5 to $25 \%$ isually obtained sith ${ }^{106} \mathrm{Ru}$.

Ir: stidies of the variables affecting ${ }^{i 06} \mathrm{hu}$ contenination of cement copper, only a slight change was found to sscur in the anount of contanination as the pH or iron concentrstion of the liquor, $c$ the rate of agitation during centation, was changed. Althourh some of these variailes affected the rate of copper cesentation, there was usually a corresponding change in the rate of ${ }^{106} \mathrm{Ru}$ cenentation so that the ${ }^{106} \mathrm{Ru}$ concentration in the copper product was relatively constant. As expected, the rutheniv contanination of the cenent copper increased when the initial concentration of ruthenil in the leach liquor was increasei while anintaining the copper concentration

\section{Table 2. Results of Cenentation Tests}

Leach Iiquor: Synthetic copper ore leach liquor after leaching of rubble fro test shot 2.

Procedure: $\quad 100 \rightarrow I$ saples of ifquor (initial pH 1.0 or 2.0) contacted with $0.35 \mathrm{~g}$ of sheet iron (detinned cans) for $1 \mathrm{mr} .^{\mathrm{a}}$

\begin{tabular}{|c|c|c|c|c|}
\hline \multirow[b]{2}{*}{ Radionuclide } & \multicolumn{2}{|c|}{ Liquor fran pH 1.0 Leach Test } & \multicolumn{2}{|c|}{ Iiguor from oH 2.0 Leach Test } \\
\hline & $\begin{array}{l}\text { ronc. in } \\
\text { Liquor } \\
\left(\text { dis } \min ^{-1} \mathrm{ll}^{-1}\right)\end{array}$ & $\begin{array}{l}\text { Anount } \\
\text { Cenented } \\
\text { (\$) }\end{array}$ & $\begin{array}{c}\text { Conc. in } \\
\text { Liquor } \\
\left.\text { (dis } \min ^{-1} \mathrm{I}^{-1}\right)\end{array}$ & $\begin{array}{c}\text { Anount } \\
\text { Cenented } \\
\text { (\$) }\end{array}$ \\
\hline${ }^{90} \mathrm{Sr}$ & 460 & $Q$ & 420 & $\ll$ \\
\hline${ }^{106}$ Thu & 2130 & 14 & 2040 & 8 \\
\hline${ }^{128} \mathrm{Sb}$ & 215 & 2 & 70 & 2 \\
\hline${ }^{137} \mathrm{Cs}$ & $116 n$ & 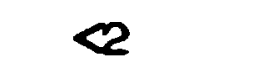 & 210 & $\boldsymbol{2}$ \\
\hline Gross gana & $890^{b}$ & 7.5 & $490^{b}$ & 7.5 \\
\hline
\end{tabular}

a60 to 70, of the copper cenented in these tests.

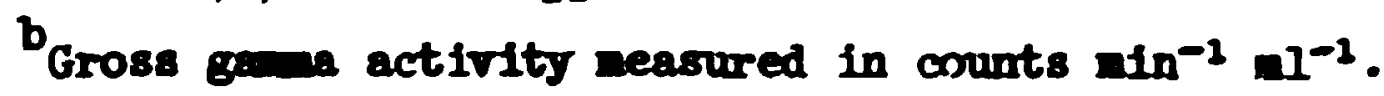


constant, but the effect was not linear. In the range of ${ }^{106}$ Pu concentretions studied (1000 to 40,000 counts $\mathrm{min}^{-1} \mathrm{~m}^{-1}$, equivalent to about 0.001 to $0.05 \mu \mathrm{Ci} / \mathrm{ml})$, increasing the initial ${ }^{206} \mathrm{Ru}$ concentration by a ractor of 10 increased the ${ }^{105} \mathrm{pu}$ concentration in the cenent copper by a facto: of about 20 (Fig. 3). About $95 \%$ of the copper was cemented in ail tests, whereas ine amount of ${ }^{106} \mathrm{Ru}$ cemented increased from $7.5 \%$ for the liquor containing the lowest concentration of ${ }^{108} \mathrm{paz} \pm 033 \%$ for the highest. I:e have estimated that the ${ }^{206} \mathrm{Ru}$ in the circulatine learh Iiyuor siolld probably not exceed $0.001 \mu \mathrm{Ci} / \mathrm{ml}$, which is about the lowest of the concentrations examined in tinis experiment.

Although certain potential radioactive activation products such as the silver and mercury isotopes cement quantitatively with copper (see Fig. 7), they should be present in extrenely small amounts and the amourits present, even if in leachable form, would be held tenuciously by the ore through ion exchange mechanisms. Fission products such as ${ }^{95} 7 \mathrm{r}-95 \mathrm{Nb}$ and $t$ in cement appreciably with the copper; however, they also are adsorbed efficiently by the ore and, therefore, should not be present in siznificant amounts in the circulating leach liquor.

After considering the quantities of each of the various radiomuclides that we would expact to be presert in the leach liquor and the beharior of these radionuclides in the cementation process, we conclude that ${ }^{108} \mathrm{Ru}$ is the only radioisotope of importance with respect to radiocontamination of the cement copper. Attempts were wade to remove ${ }^{10^{8}} \mathrm{Ru}$ from the leach liquor with various types of ion exchangers and other adsorbents, but none of these was very effective. Most of the ${ }^{108} \mathrm{Ru}$ can be removed from the recycle liquor by parisial neutralization with lime to a $\mathrm{pH}$ of about 4.5 . This nethod could be used to reduce, but not eliminate, the ${ }^{108} \mathrm{Ru}$ contanination. Fortunately, as described later (see Fig. 10 in Sect. 6.2), the ${ }^{106} \mathrm{Ru}$ is efficiently separated from the copper during electrolytic purification.

\section{COLUN IEACHTW' TESTS}

To delineate the paths followed by some of the more important radiomaclides in the copper recorery system, several coivmn lesiling--cementstion 
ORNL DWG 67-1501

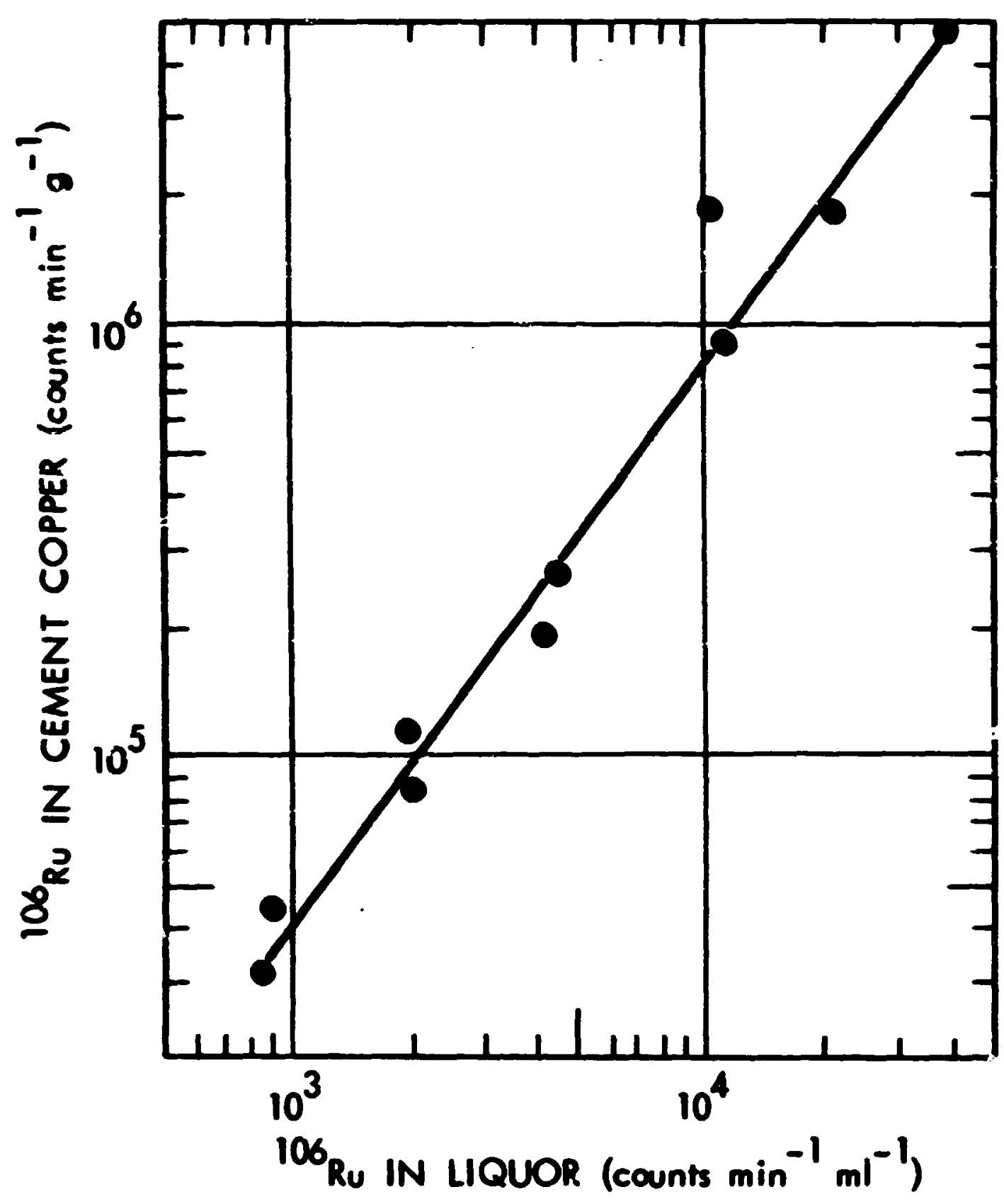

Fig. 8. Effect of Initial ${ }^{106} \mathrm{Ru}$ concentration on ${ }^{208} \mathrm{Ru}$ Contamination of cement copper. Solutions: synthetic leach liquor (pH 2.0)

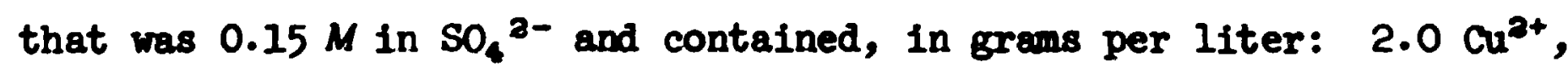
$1.0 \mathrm{Fe}^{3+}, 3.0 \mathrm{Fe}^{2+}$, and $0.5 \mathrm{HaCl}$; "spiked" with 1000 to 40,000 counts ${ }^{106} \mathrm{Ru} \mathrm{min}^{-1} \mathrm{ml}^{-1}$. Procedure: $200 \mathrm{ml}$ of solution stirred at about $25^{\circ} \mathrm{C}$ with $0.7 \mathrm{~g}$ of detinned cans for 45 min. 
tests were make. In these tests, samples of Safford ore (see Table 3) were "spiked" with the appropriate radionuclides and percolation-leached with dilute sulfuric acid by the open drainage--trickle leach method. The dissolved copper was recovered from the column effluent by cemeutation on detinned cans, and the depleter solution was acidified and recycled to the column. The behavior of the radionuclides was followed by measuring the contamination of the leach solutions and the cement copper products.

\subsection{Tritium}

If it is assumed that most of the energy of the device used to break the ore will be derived from fusion, tritium will be the dominant radiomaclide in the chimney. The tritium will be present as tritiated water and should eventually all be taken into the leaching solution. To determine the manner in which tritiated water might be washed from the ore column, a 300-g ore sample was wetted with $3 \mathrm{ml}$ of water containing about $180 \mu \mathrm{Cl}$ of tritiated water and heated at $85^{\circ} \mathrm{C}$ for 1 week in a closed 1-in.-ID column to allow equilibration of the tritiated water with any bound water in the ore. The tritiated water was added about $3 \mathrm{in.} \mathrm{from} \mathrm{the} \mathrm{bottom} \mathrm{of} \mathrm{the}$ 16-in. ore bed. About $80 \%$ of the tritium was removed in the first 0.4 bed volume of effluent when the column was leached with dilute sulfuric acid

Table 3. Composition of Safford Ore Sample

\begin{tabular}{cl}
\hline Element & $\begin{array}{c}\text { Concentration } \\
(\text { ( ) }\end{array}$ \\
\hline $\mathrm{Cu}$ & 1.27 \\
$\mathrm{Ai}$ & 7.31 \\
$\mathrm{Ca}$ & 0.006 \\
$\mathrm{Mg}$ & 0.73 \\
$\mathrm{Fe}$ & 3.71 \\
$\mathrm{Mn}$ & 0.002 \\
$\mathrm{Ni}$ & 0.011 \\
\hline
\end{tabular}

\begin{tabular}{lc}
\hline Element & $\begin{array}{c}\text { concentration } \\
(\$)\end{array}$ \\
\hline $\mathrm{TI}$ & 0.66 \\
$\mathrm{~K}$ & 4.03 \\
$\mathrm{Na}$ & 1.98 \\
$\mathrm{~F}$ & 0.10 \\
$\mathrm{C}_{3}$ & 0.28 \\
$\Sigma \mathrm{S}$ & 0.62 \\
$\mathrm{SiO}_{2}$ & 58.5 \\
\hline
\end{tabular}


(pH 1.8) at the rate of $0.12 \mathrm{ml} /$ min (Fig. 9). Less than 0.58 of the copper was dissolved in this rolve of effluent. These test results suggest that the tritiu concentration in the circulating leach liquor, and correspondingly the tritiu hazard to the plant workers, could be appreciably decreased by discarding (ratber than recycling) sane of the initial effluent that contains wost of the tritiv but little or no copper.

\subsection{Fission Frotucts}

Fission product beherior was studied by leaching 4-in.-dien coluns of Safford ore (containing added radiomalides) with dilute surfuric acid. In the first test, a 1500-g saple of wimus $1 / 2-i n$. Ore was mixed with $2000 \mathrm{~g}$ of rubble from test shot 1 ( $T a b l e ~ 1)$ and added to the colun between 500-g layers of miurus $1 / 2-i n$. ore. The ore was leacicied until about $80 \%$ of the copper was recovered. The $\mathrm{pH}$ of the dilute sulfuric acid fed to the column was adjusted in the range of 1.2 to 1.8 during the run so that the $\mathrm{pH}$ of the effluent was always above 2.0. The rubble contained a considerable smount of ucid-consuming material since more than 5 liters of solution was passed thropgh the column before the $\mathrm{pH}$ of the effluent fell below 7 . Throughout the run, the gamma activity of the leach solution was less than $20 \%$ higher than the background activity. The ${ }^{108}$ Ru content of the colvon effluent ranged from 25 to $45 \mathrm{dis}^{\mathrm{min}} \mathrm{m}^{-1} \mathrm{ml}^{-1}$, very slose to the limit of detection. Only traces of ${ }^{90} \mathrm{Sr}$ and ${ }^{137} \mathrm{Cs}$, and no ${ }^{60} \mathrm{Cs}$ or ${ }^{144} \mathrm{Ce}$, were detected in the effluents.

Fifteen batch cenentations were made during the test. of the radiomuclides present in the column, only ${ }^{106} \mathrm{Ru}$ contuminated the products. The combined products sontained about $8 \%$ of the total ${ }^{106} \mathrm{Ru}$ added to the colvm, and another $1 \%$ was in solution at the end of the test. The ${ }^{106} \mathrm{Fu}$ concentration of the cenent copper products incrsased steadily with each cementation through the first eight (FIg. 10). About 10 to $20 \%$ of the ${ }^{208} \mathrm{Ru}$ in solintion cemented with the copper in each cenentation. Following cenentations 8 through 11 , the barren effluent was adjusted with lime to a pH of 4-5 to renove ruthenium before the solution was acidified and recycied to the column. The effect of this treatment is evident in the decreased ${ }^{106} \mathrm{Ru}$ concentration of subsequent products. When the lime treatient was aiscontimued, the ${ }^{106} \mathrm{Ru}$ contanination of the cerent copper again increased 
ORNL DWG 68-842 RI

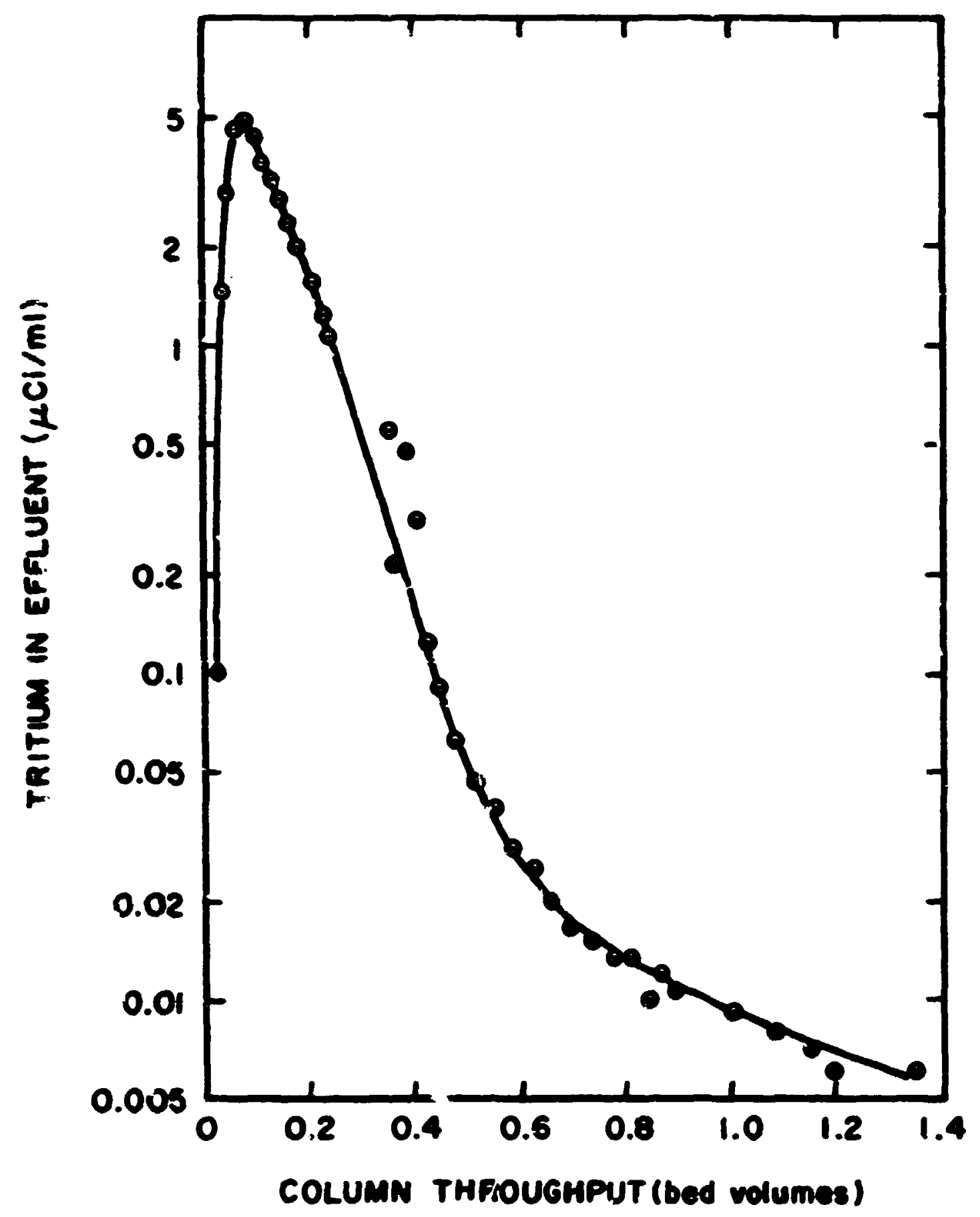

Fig. 9. Elution of Tritium Prom a column of Ore. Procedure: $300 \mathrm{~g}$ of Safford ore and $3 \mathrm{mi}$ of $\mathrm{H}_{2} \mathrm{O}$ containing $180 \mu \mathrm{Cl}$ of tritiated water were heated at $85^{\circ} \mathrm{C}$ in a stoppered l-in.-dism column for ose week. The ore was then leached with dilute $\mathrm{H}_{2} \mathrm{SO}_{4}$ ( $\mathrm{pH} \mathrm{1.8)} \mathrm{at} \mathrm{a} \mathrm{flow}$ rate of $0.12 \mathrm{ml} / \mathrm{min}$. 


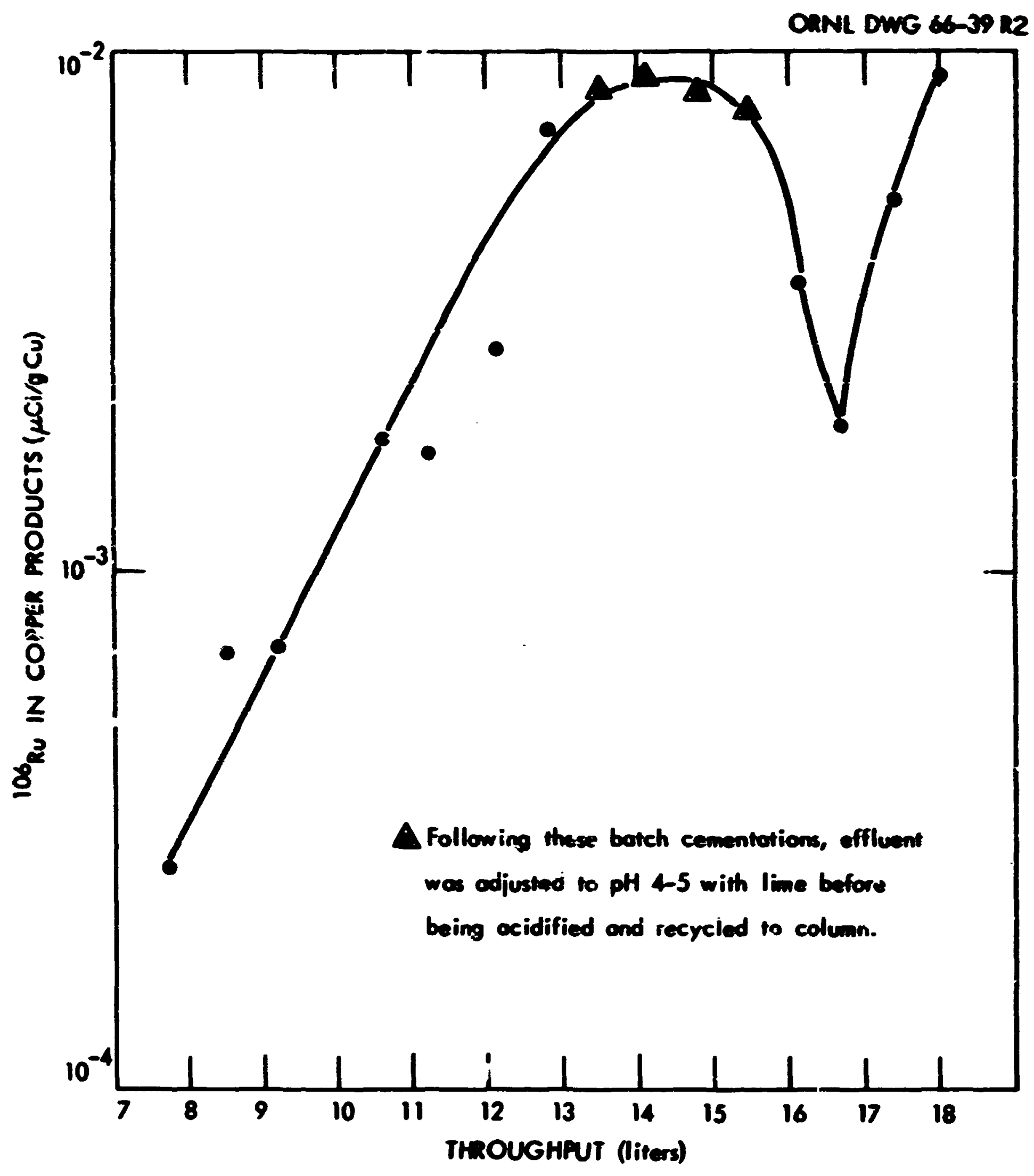

Fig. 10. Rutheniv Contemination of Cenent copper Products. Procedure: $2500 \mathrm{~g}$ of mimus 0.5-1n. Sarford copper ore and $2000 \mathrm{~g}$ or test shot rubble mixed and piaced in 4-in.-dian colvan; leached at $0.5 \mathrm{ml} / \mathrm{min}$ with recycle 1iquor; copper recovered fron colum effluesi by cementation on detinned cans; barren cenentation solution acidified with $\mathrm{H}_{2} \mathrm{SO}_{4}$ to $\mathrm{pH} 1.2-\mathrm{I} .8$ and recycled to colinn. 
steadily. About $3 \mathrm{~g}$ of $\mathrm{Ca}(\mathrm{OH})_{2}$ per liter of solution was required for adjustment to $\mathrm{pH} 4$, and $9 \mathrm{~g} /$ liter was required for adjustment to $\mathrm{pH} 5$.

A second run was made in which the fission products were added to the colvan in soluble form. A swall volume of solution containing ${ }^{85} \mathrm{Sr}$, ${ }^{96} \mathrm{Zr}-{ }^{95} \mathrm{Km},{ }^{106} \mathrm{Ru},{ }^{134} \mathrm{Cs}$, and ${ }^{244} \mathrm{Ce}$, each at a radioactivity level of $2 \times 10^{7}$ counts/min, was mixed with $1500 \mathrm{~g}$ of ore and added to the column as a layer about 2 to 8 in. above the botton of the 16-in. bed. About 65\% of the :opper was leached from the ore with dilute sulfuric acid and recovered as cement rupper in daily cementations on sheet iror. Appreciable fractions (10 to $30 \%$ ) of the ${ }^{85} \mathrm{Sr},{ }^{108} \mathrm{Ru}$, and ${ }^{144} \mathrm{Ce}$ were leached from the ore colunn. Alnost none of the ${ }^{95} \mathrm{Zr}-{ }^{96} \mathrm{mb}$ or ${ }^{134} \mathrm{Cs}$ was found in the colunn effluent because they were strongly adsorbed by the ore. The initial portions of the effluent contained principally ${ }^{86} \mathrm{Sr}$, but the concentration of this nuclide slowly decreased as the solution was recycled through the colum. The concentrations of ${ }^{106} \mathrm{Ru}$ and ${ }^{244} \mathrm{Ce}$, however, increased slorily as the $\mathrm{pH}$ of the effluent decreased to about 2 and did not change greatly thereafter. Near the end of the run, about $54 \%$ of the total cetsurty of the effluent was due to ${ }^{144} \mathrm{Ce}, 42 \%$ was tue to ${ }^{106} \mathrm{Ru}$, and $3 \%$ was due to ${ }^{85} \mathrm{sr}$. Only ${ }^{106} \mathrm{Ri}$ was found in the cement sopper in apprecizble anourte. The. ${ }^{108} \mathrm{Ru}$ contaminaticn of the copper jncreased with each sucsessive cerentation; near the end of the rur, tre products contained about $0.1 \mu \mathrm{CI}$ of ${ }^{206} \mathrm{Ru}$ per exran of copper.

\subsection{Activation Products}

In studyirg the behevior of the neutron activation products in the copper recovery system, a 2.4-g semple of jeastor-irrsdiated Safford ore that had been cooled for 52 duys (analysis in Table 4) was mixed with the layer of ore soout 4 to $8 \mathrm{in}$. above the bottan of the 16-in. bed. The 4-in.-ID ore column was leached with dilute sulfuric acid, and copper was cemelitad from the effluent until about 55\% was recovered. Cnly small fractions ( 1 to 10\%) of the radiolsotopes were dissolved during leaching, and less than $3 \%$ of ine anunts dissolved reported to the cenert copper products (Table 5). Considering these results and those obtained in the distribution and cementatior tests described in Sect. 3, the neutron 
Table 4. Neutron Activation Product content of Irradiated Safford Copper ore

(cooled 52 days)

\begin{tabular}{|c|c|c|c|}
\hline Isotope & Half-Iife & $\begin{array}{c}\text { Concentration } \\
(\mu \mathrm{CI} / \mathrm{g})\end{array}$ & $\begin{array}{l}\text { Calc. Concentration } \\
\text { After } 300 \text { Dars of Cooling } \\
(\mu \mathrm{HC} / \mathrm{g})\end{array}$ \\
\hline${ }^{66} \mathrm{Sc}$ & $84 d$ & $109 \pm 3.2$ & 14.1 \\
\hline 8 sen & $314 d$ & $11.9 \pm 1.4$ & 6.9 \\
\hline${ }^{89} \mathrm{Pe}$ & $45 d$ & $77.8 \pm 6.4$ & 1.7 \\
\hline${ }^{60} \mathrm{CO}$ & $5.3 \mathrm{~g}$ & $13.5 \pm 1.3$ & 12.3 \\
\hline${ }^{68} \mathrm{Zn}$ & $245 d$ & $11.0 \div 6.3$ & 5.5 \\
\hline${ }^{76} \mathrm{Se}$ & $120 d$ & $6.9 \pm 0.5$ & 1.6 \\
\hline${ }^{96} \mathrm{Zr}$ & $65 d$ & $1.4 \pm 0.6$ & 0.1 \\
\hline
\end{tabular}

activation products appear to be a such less irportant consideration than the fission products in recovering copper fron muclear-bzoten ore.

\section{PURTPICATIOT OP COMBII COFPER}

The cenent copper will probaily first be neited to produce irpure copper metel in the for of a consusable anode and then converted to pure copper netal by electrolysis. Alternatively, the cenent copper could be purified by dissolution in sulfuric ansid and subsequent recovery of copper netsi frow the solution by electrorinning. Sall-scale tests denonstreted that both procedures give efficient separation of copper from ${ }^{106} \mathrm{mu}$.

\subsection{Melting and Blectrolysis}

In seasuring the separation achieved by the nelting-electrolveis route, cerent sopper that was conteninated with about $8.2 \times 10^{5}$ counts of ${ }^{20} \mathrm{Ru}$ per nimute per crom was selted in a graphite crucible at 1300 to $1350^{\circ} \mathrm{C}$ in the presence of $\mathrm{CrO}, 810_{2}$, and carbon. This level of ${ }^{120 \mathrm{kn}}$ contenination, equivaleat to about $0.7 \mathrm{\mu Cl} / \mathrm{s}$, is probably at least ose or 
Table 5. Behavior of Neutron Activation Products in Copper Recoviry Systan

Test procedure: $4500 \mathrm{~B}$ of Arlzona copper or,, splked with 1rradiated ore, was leached in a 4-1n.-dicm column at a flow rate of $0.5 \mathrm{ml} / \mathrm{min}$ with synthot lc well water $\left(0.4 \mathrm{~g}\right.$ of $\mathrm{Na}_{0} \mathrm{SO}_{4}, 0.5 \mathrm{~g}$ of $\mathrm{NaCl}$ per liter) adjuated to $\mathrm{pH} 1.2 \mathrm{with} \mathrm{h}_{3} \mathrm{8O}_{4}$. The flrat $400 \mathrm{ml}$ cf solvmr efflunnt was discarded. For the ramainder of the test, copper was cemointed frem the effluent once dally, and the cementation barrene were adiusted to $\mathrm{pH} 1.2-2.0$ and recycled to the column.

\begin{tabular}{|c|c|c|c|c|c|c|c|}
\hline \multirow[b]{2}{*}{ Isotope } & \multirow[b]{2}{*}{$\begin{array}{l}\text { Amount Added } \\
\text { to } \infty \text { olvmn } \\
\text { ( } \mu C 1)\end{array}$} & \multicolumn{6}{|c|}{ Isociope Diatribution ( 8 of total init 1ally present) } \\
\hline & & $\begin{array}{l}\text { Decayed } \\
\text { During } \\
\text { Test }\end{array}$ & $\begin{array}{l}\text { In } \\
\text { Discended } \\
\text { Def .uent }\end{array}$ & $\begin{array}{c}\text { In } \\
\text { Coppor } \\
\text { Produots }\end{array}$ & $\begin{array}{l}\text { In Final } \\
\text { Inench } \\
\text { Solution }\end{array}$ & $\begin{array}{c}\text { In } \\
\text { Analyt } 1 \text { cal } \\
\text { Somples }\end{array}$ & $\begin{array}{l}\text { In colvman } \\
\text { at Ind } \\
\text { of Tosta }\end{array}$ \\
\hline$\Delta^{\circ} \mathrm{sc}$ & 260 & 22.6 & $<0.1$ & 0.07 & 1.1 & 0.7 & 75.5 \\
\hline $84 \mathrm{Nm}$ & 28.5 & 6.7 & 4.3 & 0.06 & 5.3 & 2.8 & 80.8 \\
\hline${ }^{00} \mathrm{Fe}$ & 186 & 38.0 & $<c .1$ & 0.02 & 1.9 & 1.1 & 58.9 \\
\hline $10 \infty$ & 32.5 & 1.1 & 2.9 & 0.08 & 5.7 & 1.6 & 88.6 \\
\hline $\cos _{\mathrm{Zn}}$ & 26.3 & 8.4 & 3.1 & 0.17 & 9.7 & 4.7 & 73.9 \\
\hline 78 & 16.6 & 16.4 & $<0.1$ & 0.20 & 1.2 & 0.4 & 81.7 \\
\hline $98 z x$ & 3.3 & 32.8 & $<0.1$ & 0.21 & 3.0 & $<1.0$ & 63.0 \\
\hline
\end{tabular}

By aifference. 
two orders of nagritide higner then would be expected in routine processing. The wolten copper was cooled, separated from the slag, and cast into tro anodes. Bach anode neasured $3 / 4 \times 3 / 4 \times 1 / i t$ in. and reighed about $4.8 \mathrm{~g}$. Th separation of ${ }^{106} \mathrm{Ru}$ from the copper occurred in the selting process; the anodes had essentially the sane ${ }^{106}$ Ru concentration as the cenent copper.

The two anodes wre electrolyzed in consecutive runs in the sase electrolyte ( $45 \mathrm{~g}$ of copper and $200 \mathrm{~g}$ of $\mathrm{H}_{2} \mathrm{SO}_{4}$ per liter) at a current density of bout $13 \mathrm{~A} / \mathrm{ft}^{2}$ and a cell potential of $0.2 \mathrm{~V}$. Separate copper sheets were used for cathodes in the two runs. Nbout 75, of each of the anodes vas electrolyzed, Jielding a total of about 78 of cathode copper product. The ${ }^{100} \mathrm{Ru}$ coscentration is the electrolyte increased at a constant rate throughout the tests (Fig. 11), irificating that the ${ }^{100} \mathrm{Ru}$ ws uniforily distributed (alloged with the copper) in the anodes. About two-thinds of the ${ }^{106}$ Ru released fro the modes was found in the electroirte, and onethind of it was found in the "anode nd" that settled to the botto of the electroijtic cell. Only 1 to $2 \%$ was found in the cathodes; the rirst cathode product contained 6800 counts of ${ }^{106} \mathrm{Ru}$ per nimute per gran, and the second contained 14,000 counts $\mathrm{nin}^{-1} \mathrm{~B}^{-1}$. These concentrations are loser by factors of 120 and 60 , respectively, than the concentration in the cenent copper.

\subsection{Dissolution and Electrowiming}

When ${ }^{108} \mathrm{Ru}$-couteninated cenent copper was dissolved in dilute serated suisuric acid at $80^{\circ} \mathrm{C}$, about tro-thirds of the rutbeniv dissolved in the acid solution. About $0.5 \%$ of the cenent sopper was ineolvble in the acid and settled out as a finely divided tlack sludge that rese-bled the "anode md" forned during electrolutic purification of anoies that were cast fron cenent copper. This sluage contained the other one-third of the rutheniva.

The ${ }^{106}$ Ru contenination of copper producte prepared by electrourinning copper frow the couthenated electrolvte solutions increased fron 0.0014 to $0.20 \mu \mathrm{Cl}$ of ${ }^{206} \mathrm{Pu}$ per are of copper as the ${ }^{20 \%} \mathrm{Du}$ soncentration in the electrolyte was increased from 0.0027 to $0.43 \mu \mathrm{Cs} / \mathrm{hl}$ (P18. 12). In these tests, the electrolyte solutions initially contained 25 \& of copper and 


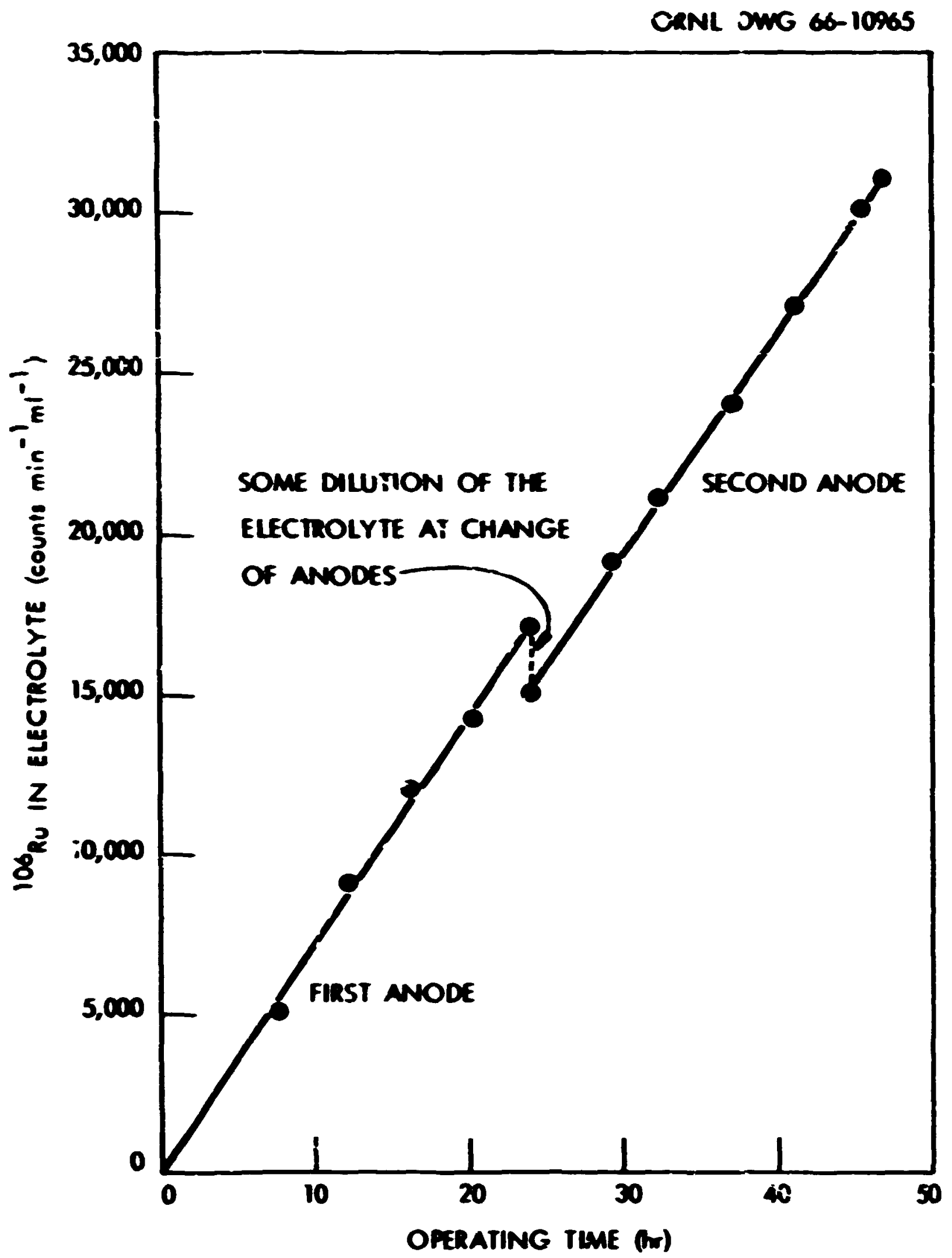

Fig. 11. Accurulation of ${ }^{106} \mathrm{Ru}$ in the Cell Electrolyte. Anodes containing $8.2 \times 10^{6}$ counts of ${ }^{106} \mathrm{Ru}$ per nimute per gran were electrolyzed in a solution containing $45 \mathrm{~g}$ of copper and $200 \mathrm{~B}$ of $\mathrm{H}_{2} \mathrm{SO}_{4}$ per ifter. 


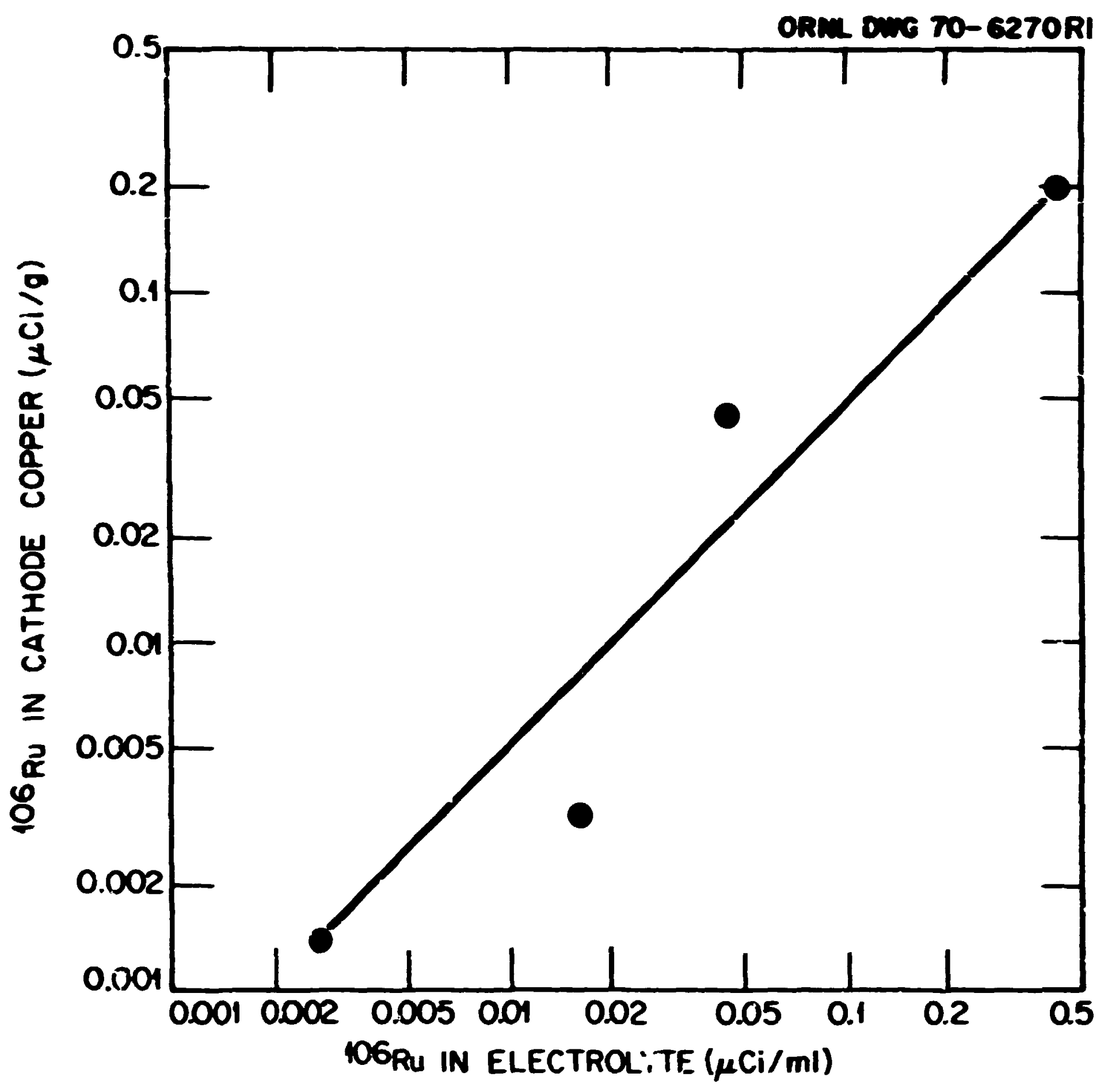

Fig. 12. Effect of ${ }^{106} \mathrm{Ru}$ Concentration in the Cell Electrolyte on the Contanination of Cathode Copper Products from Electrowinning Cell. conditions: cell temperature of $55^{\circ} \mathrm{C}$ and current density of $10 \mathrm{~A} / \mathrm{ft}^{2}$. 
$50 \mathrm{~g}$ of $\mathrm{H}_{2} \mathrm{SO}_{4}$ per 11t.er. Copper was recovered from samples of the electrolyte solutions by treatment in a small cell for $6 \mathrm{hr}$ at a current dersity of about $10 \mathrm{~A} / \mathrm{ft}^{2}$ and a cell potential of cbout $2 \mathrm{y}$. Both of the electrodes wre platinum, and the ce!l temperature was $55^{\circ} \mathrm{C}$. The cathode deposits contoined about $14 \%$ of the copper and about $0.2 \%$ of the ${ }^{106}$ Ru initiaily present in the electrolytes. The cathoie copper products contained less ${ }^{20}$ Ru. by factors of $i 20$ to 300 , than the cement copper; this is about the same degree of seraration that was obtained by melting and electrolysis.

\section{3 control of ${ }^{106}$ Rivi}

As described 1: Sects. 7.1 and $7.2,{ }^{206} \mathrm{Ru}$ accumulates rapidly in the cell electrolyte and eventual 3 would beccrs a significant radiation problea. Also, contsination of the rathode copper product increases as the ${ }^{106} \mathrm{Pi}$ soncentration in the solution is increased. Consequentiy, some wears of preventing excessive bullduf of ${ }^{20}$ Ru in the solution would be required. Atteapts to scavinge ${ }^{200} \mathrm{Pu}$ from the electrolyte by sorption and solvert extraction techn'ques were not successful. oxidation of the muthenilu, followed by sparging of the solution to remove volatile ruthenium tetroxide, geve good results, and this procedure appears to provide a satisfactory solution to the problem.

In the initial tests, the ruthenium was oxidized with sodium persulfate and the resultine oxidation product was removed by sparging the heated (or boiling) solution with air. Although as much as $80 \%$ of the ruthenivm was removed from solution, most of it plated out on the walls of the equipment. Better results were obtained by using ozone as an oxidant. In this case, the volatilized ruthenium was carried efficiently from the system in the gas stream.

In batch tests, up to $90 \%$ of the ${ }^{200} \mathrm{Ru}$ was volatilized in $.15 \mathrm{~min}$ at $90^{\circ} \mathrm{C}$ from simulated electrolyte solutions by sparging with air containing about 30 mg of ozone per 1iter. The removal of ruthenium was more efficient at $90^{\circ} \mathrm{C}$ than at $90^{\circ} \mathrm{C}$. Use of ozonized oxygen instead of ozonized air had little effect on the ${ }^{106} \mathrm{Ru}$ removal afficiency.

Continuous Tests. - In a series of tests at $90^{\circ} \mathrm{C}$, preheated elecirolyte was fed contimously to an agitated vessel that had a capacity of about $45 \mathrm{ml}$ of solution. Ozonized air was preheated and dispersed into the 
solution through a fine glass frit. From 80 to $90 \%$ of the ${ }^{206}$ Ru was vilatilized usirig a solution resilience time of 15 ain, provided that the ewouni of ozone supplied was wore than 0.5 wole per nole of $\mathrm{Fe}^{2+}$ in the electrolyse; none of it was rewored when the wole ratio was less than 0.5 (Table 6). These results are in accord with the stoichionetric requirements for ozone, based on the reection

$$
\mathrm{O}+2 \mathrm{Fe}^{2+}+2 \mathrm{H}^{+}+2 \mathrm{Pe}^{3+}+\mathrm{O}_{2}+\mathrm{H}_{2} \mathrm{O}
$$

They show that ozone equivalent to the $\mathrm{Fe}^{\mathrm{a}+}$ must be supplisd before an ruthenium can be oxidized and voiatilized. A relatively anall excess of ozone over that needed to oxidize the $\mathrm{Fe}^{2+}$ is necessary for efficient ruthenium renoval.

Table 6. Oxidation and Volatilization of ${ }^{106} \mathrm{Ru}$ Prom Electrolyte Solutions with Ozonized Air

Procedure: About $300 \mathrm{cc}$ of air per minute, containing about $30 \mathrm{mg}$ of ozone per liter, was dispersed through a fine glass frit into simulated electrolyte solution ( $2 \mathrm{M} \mathrm{H}_{2} \mathrm{SO}_{4}$ containing $50 \mathrm{~g}$ of copper per liter and $\mathrm{Fe}^{2+}$ as shown; traced with $\sim 5 \times 10^{\circ}$ counts nin ${ }^{-1}$

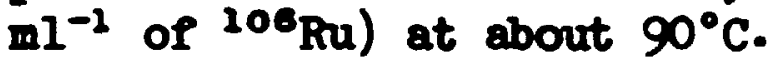

\begin{tabular}{|c|c|c|c|c|}
\hline $\begin{array}{l}\text { Run } \\
\text { No. }\end{array}$ & $\begin{array}{c}\mathrm{Fe}^{2+} \text { Concentration } \\
\text { in Electroljte } \\
(M)\end{array}$ & $\begin{array}{c}\text { Calculated } \\
\text { Mole Ratio, } \\
\mathrm{O}_{3} / \mathrm{Fe}^{2+}\end{array}$ & $\begin{array}{l}\text { Solution } \\
\text { Residence } \\
\text { Time }^{a} \\
(\min )\end{array}$ & $\begin{array}{c}\text { Amountb } \\
\text { of }{ }^{108} \mathrm{Pu} \\
\text { volatilized } \\
\text { ( }(\$)\end{array}$ \\
\hline 1 & 0 & - & 15 & 80 \\
\hline 2 & 0.05 & 1.2 & 15 & 90 \\
\hline 3 & 0.10 & 0.66 & 15 & 81 \\
\hline 4 & 0.20 & 0.37 & 15 & 0 \\
\hline 5 & 0.20 & 0.13 & 7.5 & 0 \\
\hline 6 & 0.20 & 0.74 & 30 & 92 \\
\hline
\end{tabular}

asolution residence time in the reactor, which had a 45-ml boldup volume, was varied by varying the solution feed rate in the range of 1.5 to $6 \mathrm{ml}$ per minute.

bverage of four samples of effluent electrolyte soluition tairen during last half of each experimental run. 
Inese results suggest that the ${ }^{108} \mathrm{Tu}$ concentration in the cell electrolyte could be controlled at a tolerable level by continuously withdrading cell electrolyte at a low rate (possibly 10\% of the electrolyte imentory per day) for a rutheniv resoval treatment and then returning the partially decontaminated solution to the cell. Arailaile data from production plants indicate that tis $\mathrm{Fe}^{2+}$ concentratic i in the electrolyte is usually in the range of 0.06 to $0.05 \mathrm{M}$. Assuming that the maximu $\mathrm{Fe}^{2+}$ concentration is in this range, the estimated cost for ozone to treat $10 \%$ of the electrolyte volume per day would be less than 0.01 per pound of recovered copper.

Rutheniu Trapping. - In the ${ }^{106} \mathrm{Ru}$ rolatilization experiments, the ${ }^{106}$ Ri was quantitatively renored from the off-gas strean by passing it through a bed of activatea carbon; scrubbing the off-gas with $I M$ waOH solution was only about $95 \%$ efficient. A 1-8 38ple of carbon (Type OL, 20-50 mesh, Pittsburgh Chemical Company) sorbed $5 \mu C 1$ of ${ }^{200} \mathrm{Ru}$ without any measurable breakthrough. A saturation loading test (with breakthrough) showed the carbon to hare a capacity of 2 acl of ${ }^{106}$ Ru per gran under the prevailing test conditions.

Sludge Reoral. - Since about one-third of the ${ }^{206} \mathrm{Ru}$ was found in the "anode mut" that accumlated in the electrolytic cell (see Sect. 7.1), sane provision would be needed for rewiag this radioactive sludge from the cell and disposing of it.

\section{SOLVEIT EXIRACTION OF COPPER}

As an alternative to the cementation process, copper can be recorered from dilute acid liquors by solvent extraction (Pig. 3). The extracted copper is stripped from the solvent with sulfuric acid and purified directly by electrowinning. As mestioned previousiy, this process is now used comercially and is claimed ${ }^{9}$ to be a more econonical route to the recovery of copper metal than the cementation-electrolysis process. The behevior of radiomuclides during solvent extraction was first examined in betch tests and then in a sall-scale colum leaching--8oivent extraction--electrowinning circuit. Results of the tests indicate that the copper product should be essentially free of radioactive contaminants. 


\subsection{Batch Extraction Tests}

Two : amercially available copper extraction reagents, LDX-64 (General Mills Comptury) and Kelex 100 (Ashland Chenical Oomany), were tested. Both are cation exchange reagents and efficient copper extractants. The Kelex 100 is supplied as Kelex 100-25, a 25\% solution of Kelex 100 in tridecanol.

Isotherns for the extraction of copper from a simuled leach liquor that contained 2 B of copper per liter showed nerinum copper loadings of about $2.3 \mathrm{~g} / \mathrm{liter}$ for $15 \mathrm{gol}$ \& kelex 100-25 in kerosene and about $2.9 \mathrm{~g}$ per liter for $10 \mathrm{v} / \mathrm{v}$ \& IDX-64 in Varsol (FIg. 13). The pll of the aqueous phase decreased from an initial value of 2.0 during extraction owing to the exchange of copper for hydrogen 1ons; after extraction of essentially all of the copper, It was 1.5 in the test with LDX-64 and 1.35 in the test with Kelex 100. Relex 100 is a stronger copger extractant (as eridenced by the steeper isotherm at low copper loadings) and capabis of nore efficlent copper extraction at higher acidities than IDX-64*. curversely, copper is more readily steipped from LDK-64 with sulfuric acid. Stripping tests with $2 \mathrm{M} \mathrm{H}_{2} \mathrm{SO}_{4}$ indicated that the maxime copper loading of the strip solution obtainabie at roce tesorature when extracts containing about $2.5 \mathrm{~g}$ of copper per I1ter are stripped would be sbout 50 g/liter for 10 w/T $\$$ IIX-64 in Varsol and 30 sifilter for 15 vol \& relex 100-25 in kerosene.

of 11 radiomuclides tested, only $96 \mathrm{zr}-94 \mathrm{bb}, 60 \mathrm{pe}$, and $110 \mathrm{Ag}$ bad extraction coefficierts higher than 0.01 in the pH range of 1.5 to 2.5 when $10 \mathrm{w} / \mathrm{V}$ \& LDX-64 in Varsol was wed as the extractant (F16. 14). These tests were made with simlated copper ore leach 1 iquors that contained $0.2 \mathrm{~g}$

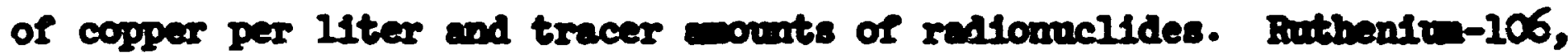
the nost trovblescose conteninant in the cenentation process, bad extrection

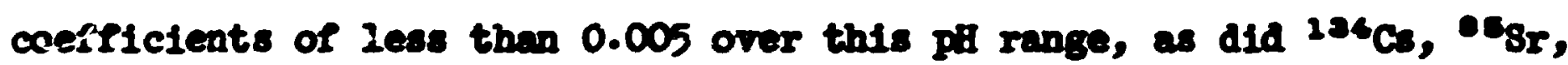

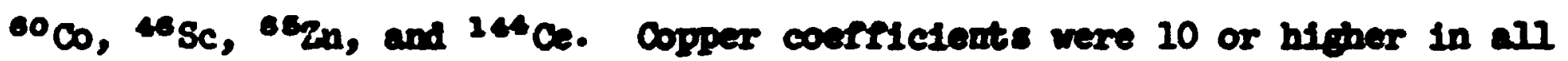

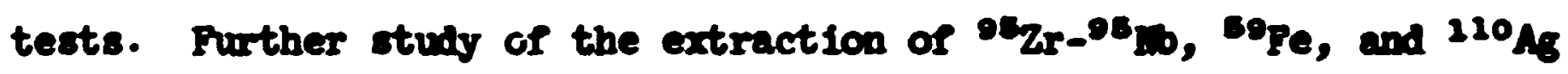
showed the extractions of the firot tio to be tive dependent. The extrection

Very recently, the General Mills Corpans announced the avilablitity of LIX-64I, a nodification of IIX-64, mich extracts copper at hiposr ac1d1ties than does IDX-64. We heve not tested the IDX-64I naterial. 
ORNL DWG 71-2004RI

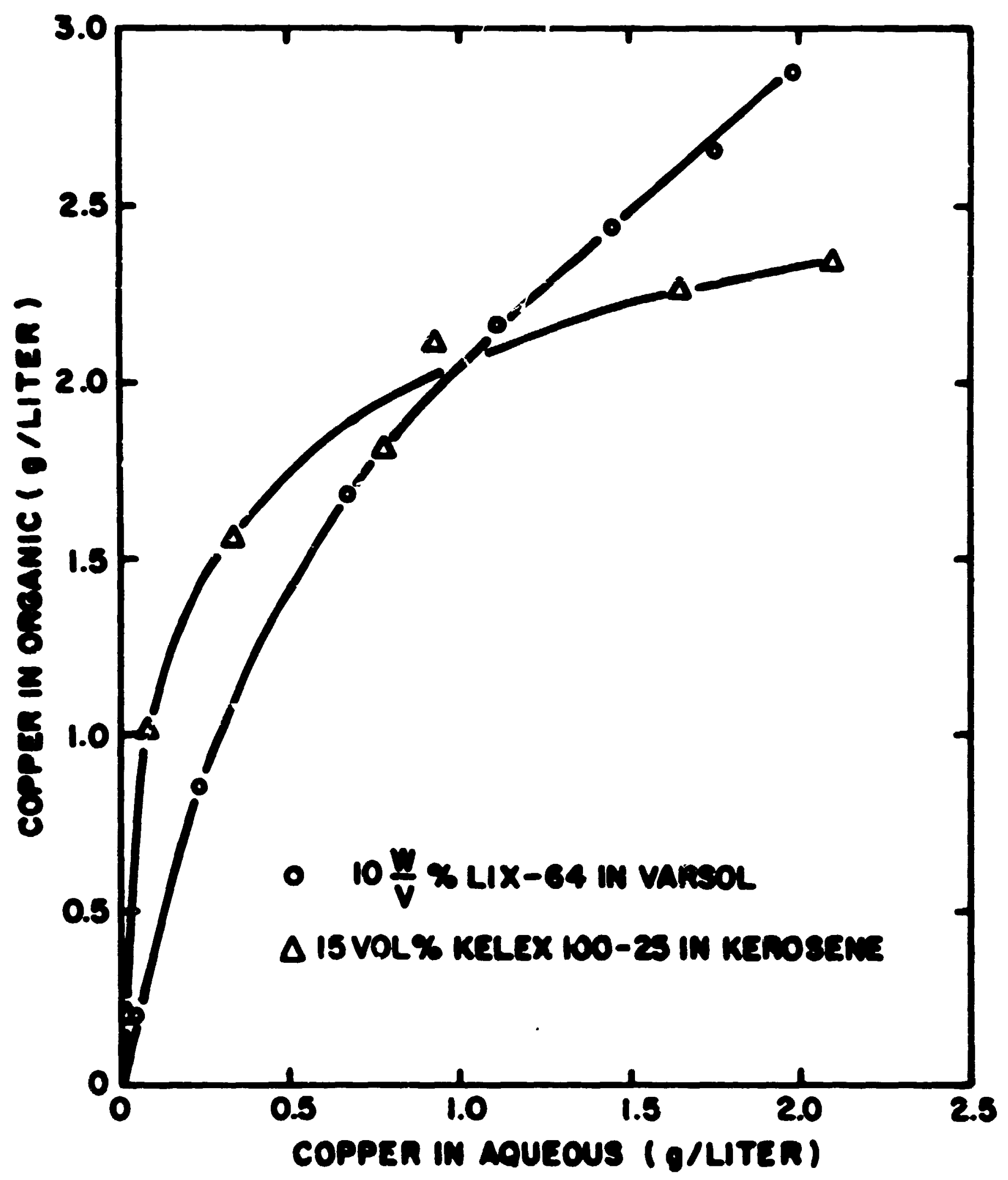

Fig. 13. Copper Extraction Isotherms. Aqueous phase: simulated copper ore leach liquor (Initial pH 2.0) that was $0.1 \mathrm{M}$ in $\mathrm{SO}_{4}{ }^{2-}$ and contained, in g/liter, $2.0 \mathrm{Cu}^{2+}, 1.0 \mathrm{Pe}^{2+}, 3.0 \mathrm{Pe}^{2+}$, and $0.5 \mathrm{raCl}$. 


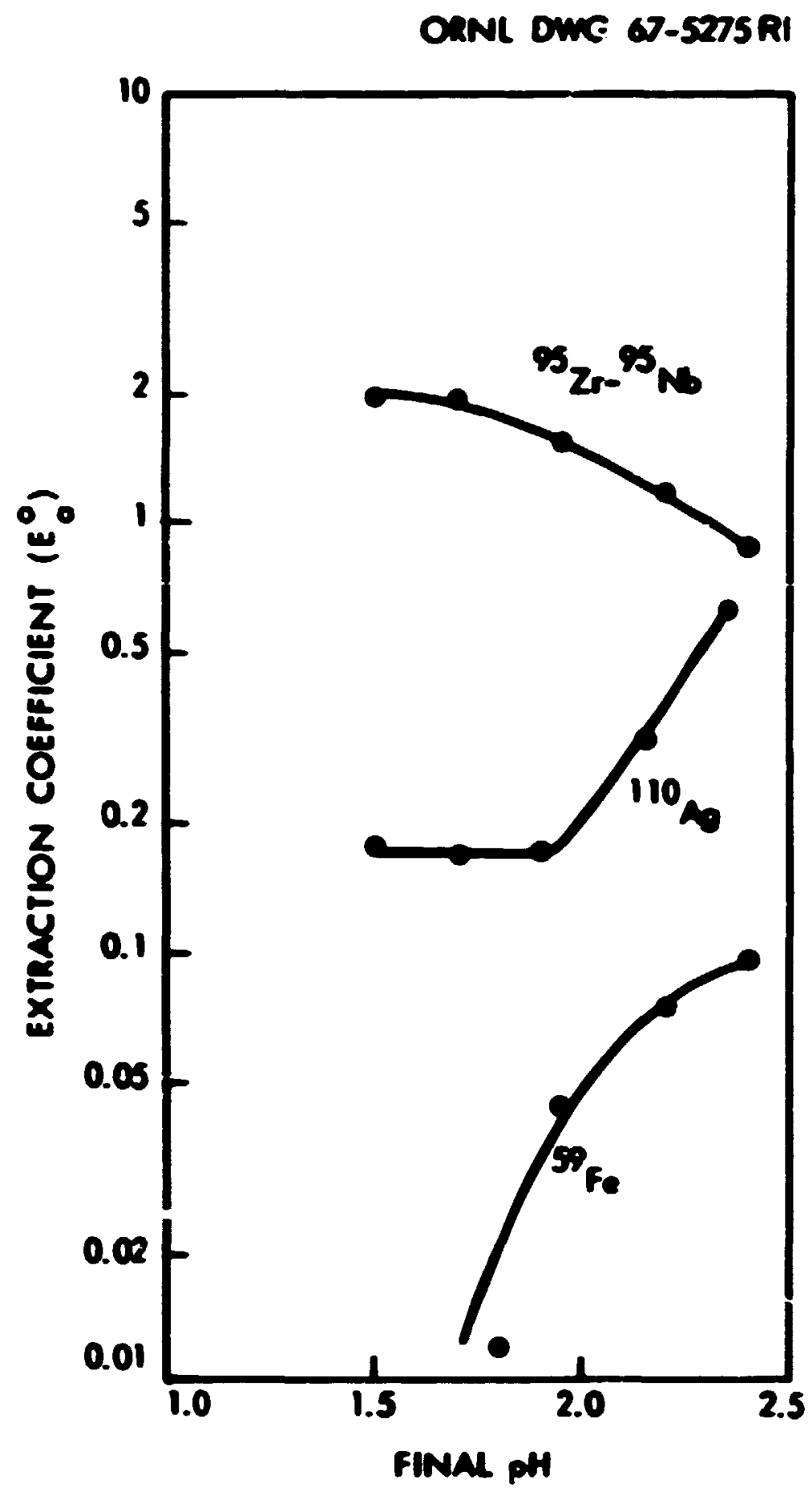

Fi8. 14. Effeet of pH on the Bxtraction of Radioactive conteninants with LDX-64. Organic phase: $10 \mathrm{w} / \mathrm{v}$ \& LDX-64 in Varsol. Aque ous phase: simulated copper ore leach liquor that was $0.1 \mathrm{M}$ in $\mathrm{SO}_{4}{ }^{2-}$ and contained, in E/liter, $0.2 \mathrm{Cu}^{2+}, 1.0 \mathrm{Pe}^{2+}, 3.0 \mathrm{Fe}^{2+}$, and $0.5 \mathrm{haC}$; traced with the radioactive controinants. Contact: 5 nin at phase ratio of $1 / 1$. Radiomuclides that had extraction coefficients less than

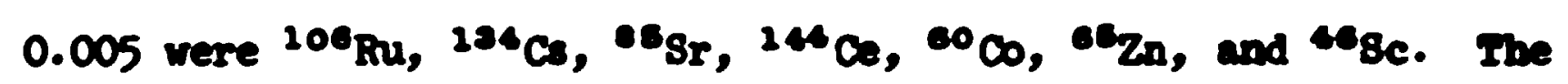
coefficient for distribution of tritiated water between the phases aleo was rery lor $(<0.005)$. 
coefficient for ${ }^{80}$ Pe leveled off at about 0.15 after a 30 -min contact period. After $60 \mathrm{~min}$, the coefficient for ${ }^{96} \mathrm{gr}-96 \mathrm{Mo}$ was 50 and still increasing. Essentially all of the ${ }^{89} \mathrm{Fe}$ but, only about $30 \%$ of the ${ }^{110} \mathrm{AB}$ and 20,3 of the ${ }^{96} \mathrm{Zr}-98 \mathrm{Ko}$ were stripped fran the extracts with $2 \mathrm{M}_{2} \mathrm{SO}_{4}$ in a $10-\pi$ in contact at a phase ratio of $1 / 1$.

Extraction coefficients for the radiomuclides were slightly higher with 15 vol 8 Kelex 100-25 in kerosene (PIg. 15). In 10-min extractions, coefficients were less than 0.01 for ${ }^{20} \mathrm{Ru},{ }^{134} \mathrm{Cs}$, and ${ }^{144} \mathrm{Ce}$, and between 0.01 and 0.05 for ${ }^{60} \mathrm{Co},{ }^{88} \mathrm{Sr}$, and ${ }^{128} \mathrm{Sb}$. As in the tests with $\mathrm{LIX}-64$, extractions of ${ }^{85} \mathrm{Zr}-{ }^{25} \mathrm{NO},{ }^{110} \mathrm{Ag}$, and ${ }^{80} \mathrm{Pe}$ rere 81 gnificant. Extraction coefficients for ${ }^{96} \mathrm{Zr}-{ }^{95} \mathrm{No}$ were about 30 . Iror. extraction was time depenIent; the extraction coefficient increased from 0.05 to 0.25 when the contact tine was increased fron 5 to $60 \mathrm{~min}$. Waterial balances for $210 \mathrm{Ag}$ were poor, and data for extraction of this radiomalide are not shown; $80{ }^{110} \mathrm{Ag}$ extraction did occur, bowever. The extraction coefficient for copper was 8 at a pH of 0.9 and more than 200 at a pH of 2.3 and higher.

Fortunately, it is anticipated that the concentrations of ${ }^{98} \mathrm{Zr}-98 \mathrm{su}$, ${ }^{39} \mathrm{Fe}$, and ${ }^{110} \mathrm{Ag}$ in the leach liquors obtained by in situ leaching of muclear-broken ore sbould be extreneiy low; therefore, ihese radiomalides should not present any problen in copper recovery by solvent extraction.

\subsection{Dewonstration or colunn Leaching--} Solvent Extraction--Electrowinning Flowsheet

A mall-scale cyclic coluan leaching--solvent extraction--electrowinning circuit was operated to measure the separation of copper from sadoactive contaminants by this process. Although relatively large mounts of several radiomuclides in solvible form were added to the colum of ore, the radioactivity of the copper netal products was so low that it was detectable only in a special low-level counting facility. A detailed description of the deconstration run follows.

A flow diagrem for the test circuit is shown in Fig. 16. The 4-in.-ID columan was loaded with 4500 g of minus 0.5-15. Safford ore. About $25 \mathrm{ml}$ of solution containing ${ }^{88} \mathrm{Sr},{ }^{98} \mathrm{Zr}-{ }^{96} \mathrm{Mb},{ }^{108} \mathrm{Ru},{ }^{128} \mathrm{gt}$, and ${ }^{234} \mathrm{Cs}$, each at the radioactivity level of $2 \times 10^{7}$ counts/min, was added to the ore layer about 3 to $7 \mathrm{in.} \mathrm{from} \mathrm{the} \mathrm{bottom} \mathrm{of} \mathrm{the} \mathrm{15-1n.} \mathrm{bed.} \mathrm{Due} \mathrm{to} \mathrm{different} \mathrm{gama}$ 
Comen owe n-2004 na

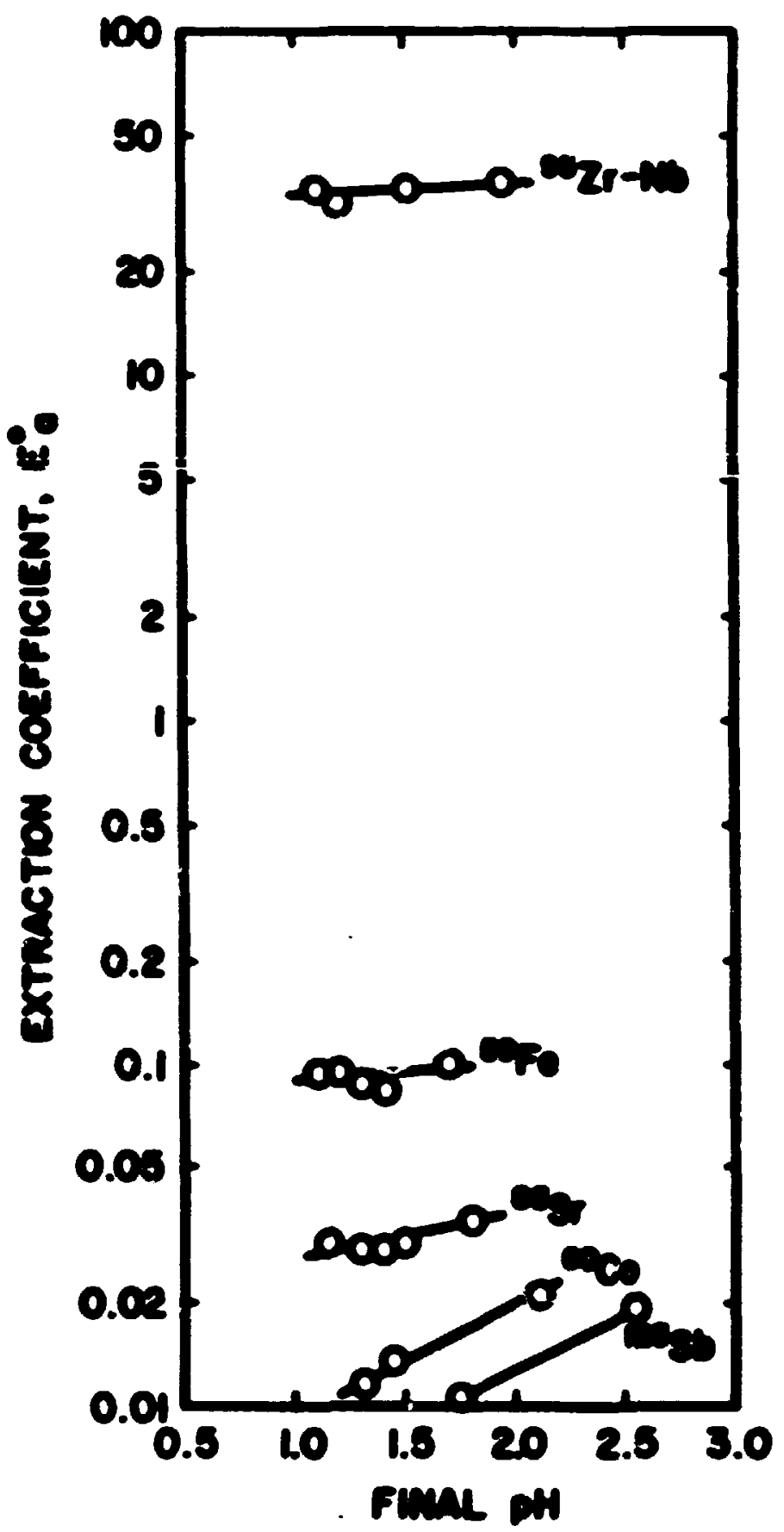

F1g. 15. Extraction of Radioactive Conteninants with Felex 100. Organic phase: 15 voi \& Kelex 100-25 in kerosene. Aqueous phase: simulated copper ore leach liquor that was $0.1 \mathrm{~m}$ in $\mathrm{SO}_{4}{ }^{2-}$ and contained, in $\mathrm{g} /$ liter, $0.2 \mathrm{Cw}^{2+}, 1.0 \mathrm{Fe}^{2+}, 3.0 \mathrm{Pe}^{2+}$, and $0.5 \mathrm{MaCl}$; traced with the radioactive contrainants. Contect: 10 min at phase ratio of 1/1. Radivinuclides that had extraction coefficients leas thas 0.01 were ${ }^{106} \mathrm{Ru},{ }^{134} \mathrm{Cs}$, and ${ }^{144} \mathrm{Ce}$. 
OAML OWG. 70-0957-m

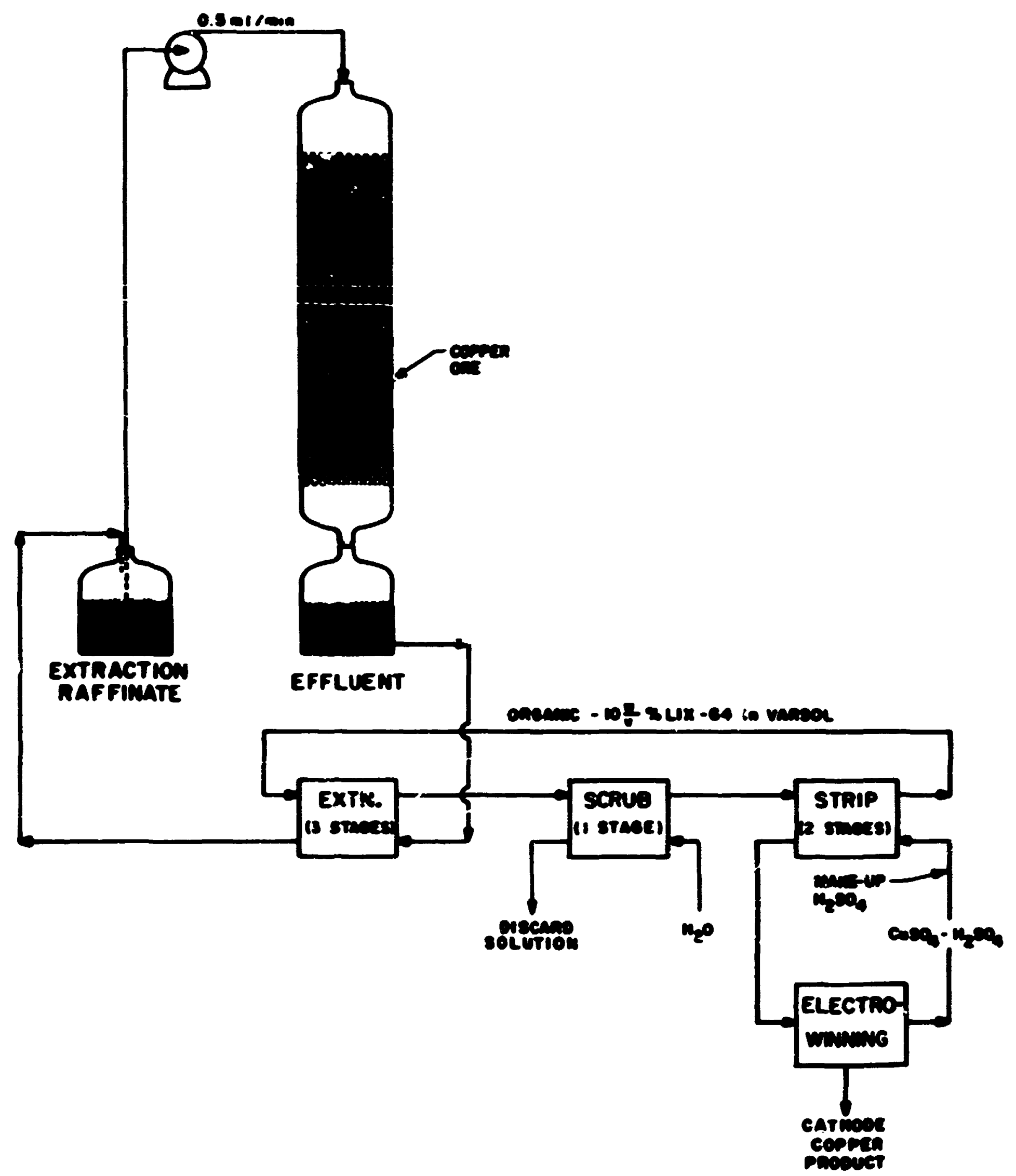

Fig. 16. Flowsheet for column Leaching--Solvent Extraction-Electrowinning Circult. 
counting efficiencies for tha radionuclides, the eounts of each ranged

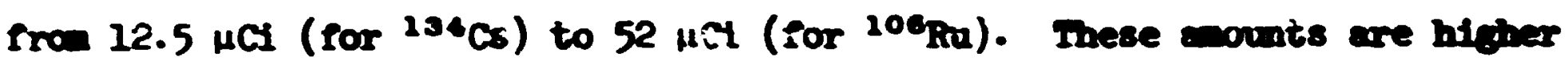
by factors of 4 to 40 than ihose we esisate would be in the maclear-broten chinney (in this case, strontiv would be present as ${ }^{\circ}$ Sr rather the ${ }^{\circ} 8$, and cesiv would be present as ${ }^{237} \mathrm{Cs}$ rather than ${ }^{204} \mathrm{Cs}$ ) in leachble four 300 days arter use of a 90,3 rusion--10, plutonim fission device.

The leach solution flor sate was about $0.5 \mathrm{~m} /$ min. Ieacining was started with simalated well sater $\left(0.5 \mathrm{~g}\right.$ of FaCl and $0.4 \mathrm{~g}$ of $\mathrm{FasO}_{4}$ per

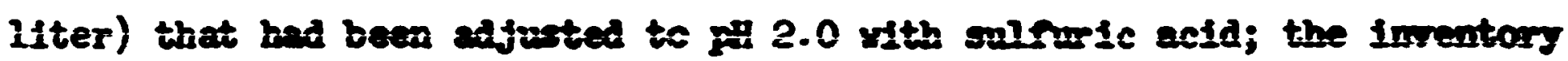
of circulating leech solution in the systen was about $1200 \mathrm{ml}$. In the initial part of the test, the colvon effluent had a fil sbove 4 and a $10 \mathrm{r}$ copper concentration; the enfluent, whici was collected in daily batches, was not treated by solvent extraction but, insteed, was acidified to a fH of 2.0 with sulfuric acid and recucled to the colven. The colvent extraction circuit we activated wheis the copper concentration in the efrlvent reached about 2 \& per liter. Copper vas recovered from the effluent by batch countercurrent extraction with $10 \mathrm{v} / \mathrm{\gamma}$ \& IDC-64 in Varsol, and the copper-barren liquor was recycled to leaching. The solvedt extract was scrubbed with water to rewove entrained liquor and stripped by batch countercurrent contact with about $4 \mathrm{I}_{\mathrm{a}} \mathrm{SO}_{4}$; then the stripped solvent was recycied to extraction. The strip solution was treated in a sall electrolytic cell to deposit part of the copper and subsequently recycled to the stripping system.

The concentration of copper in solut locs in each of the process circults during the run 18 shown in Fig. 17.

Leaching CIrcuit. - Based on analyses of the head ore and analyses of the colum feed and effluent. about $65 \%$ of the copper was leached fron the ore in 24.6 Iiters of efrluent (about nine colun rolveses). About 6.6 liters of solution passed through the colvan before the copper concentration reached 28 per liter (F18. 18). The pH of the colutica fed to the colum decreased to about 1.4 after startup of the solvent extraction system. The copper concentration in the colun effluent reached a maxim at an effluent pH of about 3.5, where nont of the copper was leached. The test was discontinued when the copper concentration in the effluent fell to $1.2 \mathrm{~g}$ per I1ter. 
ORNL DWG. $70-8958$

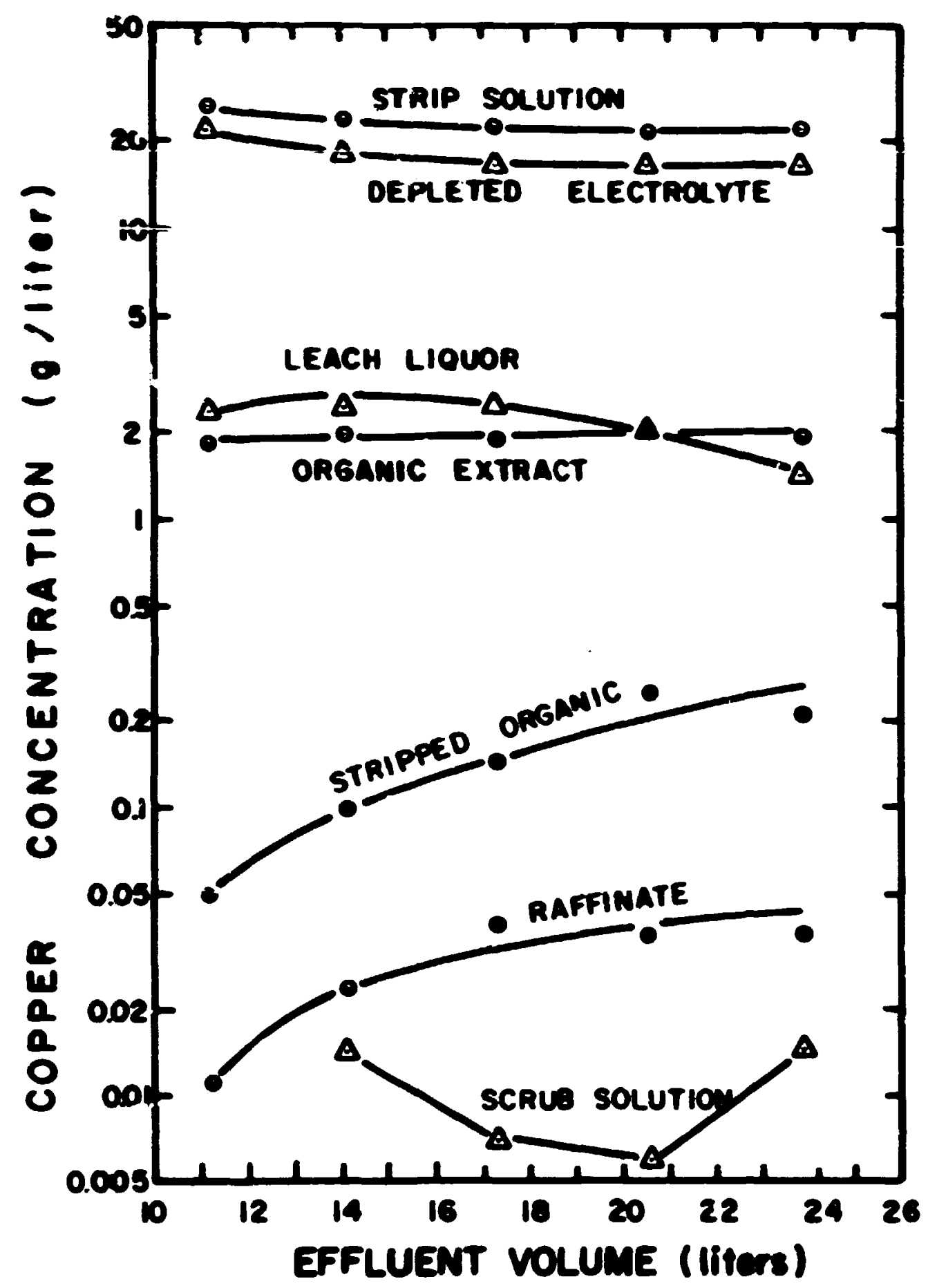

Fig. 17. Profile of Copper Concentrations in the Copper Recovery System. 
ORNL DWG. 70-8959

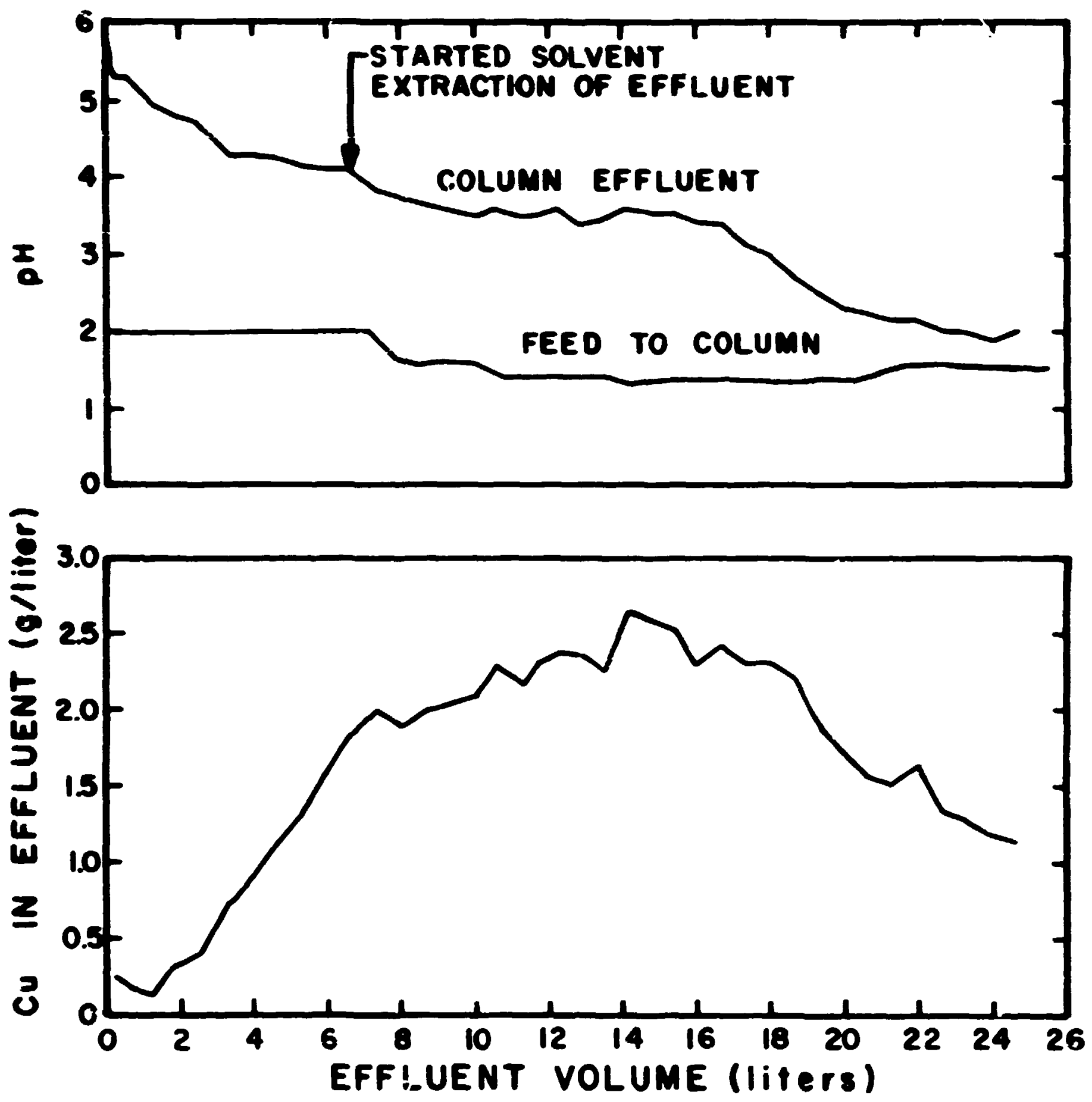

Fig. 18. Copper Concentration and pH of the Column Effluent. 
Recause of ion exchange retention on the ore, only minor fracticns of the radionuclides reported to the column effluent. Strontium-85 was the dominant radionuclide in the initial ef fllient, and ${ }^{105} \mathrm{Ru}$ was daminant in the final efiluent (Fig. 19). About $20 \%$ oi the ${ }^{a b}$ is was in solution during the first half of the test; about $4 \%$ of it was in sciution at the end. The amount of ${ }^{1{ }^{c s} \mathrm{Ru}}$ in soluticn increased from less than $1 \%$ in the early part of the test, when the pll of the effluent was high, to about $16 \%$ at the end. iess ihan $1 \%$ of the ${ }^{176} \mathrm{Sb}$ or ${ }^{134} \mathrm{Cs}$ was in solution at a given time, and $96 \mathrm{r} r-96 \mathrm{rJ}$ was not detected in any of the offluent samples.

Solvent Extraction Circuit. - Copper was recovered from the effluent by batch countercurrent extraction in three stages with $10 \mathrm{w} / \mathrm{v} \%$ IDX -64 in Varsol. The organic-to-aqueous phase ratio in the extraction system was adjusted to provide a solvent coprer lcading of about $2 \mathrm{~g}$ per liter. Based on anaiyses of the leach liquor and raffinate samples, more thar $78 \%$ of the copper was extracted (Fig. 17). The extracts contained from 1.8 to $2 . \mathrm{C} \mathrm{g}$ of copper per liter, and the raffinates contained 0.01 to $0.04 \mathrm{~g} /$ lite: The copper was separated efficiently from the radioactive contaminants in the extraction step. Most of the samples of solvent extract had gross gama count rates jesi than 5\% higher than bac'iground; the highest count rate for any sample was only about $8 \%$ above backeround.

The solvent extract was scrubbed with water at an organic/aqueous phise ratio of 20/1, primarily to prevent carry-over of any entrained leach liquor to the strip section. The scrub solutions contained $0.01 \mathrm{~g}$ of copper per liter at a pH of about $2 .+$ and essentially no radionuclides; the gross gemna activity of the individual solutions was less than $10 \%$ atove background. In this test, the scrub solution was discardad; in process operation, it could be used in the makeup of leach solution.

The two-stage batch countercurrent stripping system was star + ed with about $4.5 \mathrm{~N} \mathrm{H}_{2} \mathrm{SO}_{4}$. The residial acid co:ıcentration decreased to about $4 \mathrm{~N}$ after contact with the extract at an organic/aqveous phase ratio of $14 / 1$ to vield copper sonceritrations of about $26 \mathrm{~g} /$ /iter and $0.05 \mathrm{~g} /$ iter in the aqueous and the stripped organic, respectively. After a strip solution inventory sufficient to operate the electrowinning system was genereiced, the stripping yhese ratic was adjusted to $2.8 / 1$. Under these conditions, the cuncentracion of copper in the stripped organic wos usualiy in the 
OANL DWe 70-8980

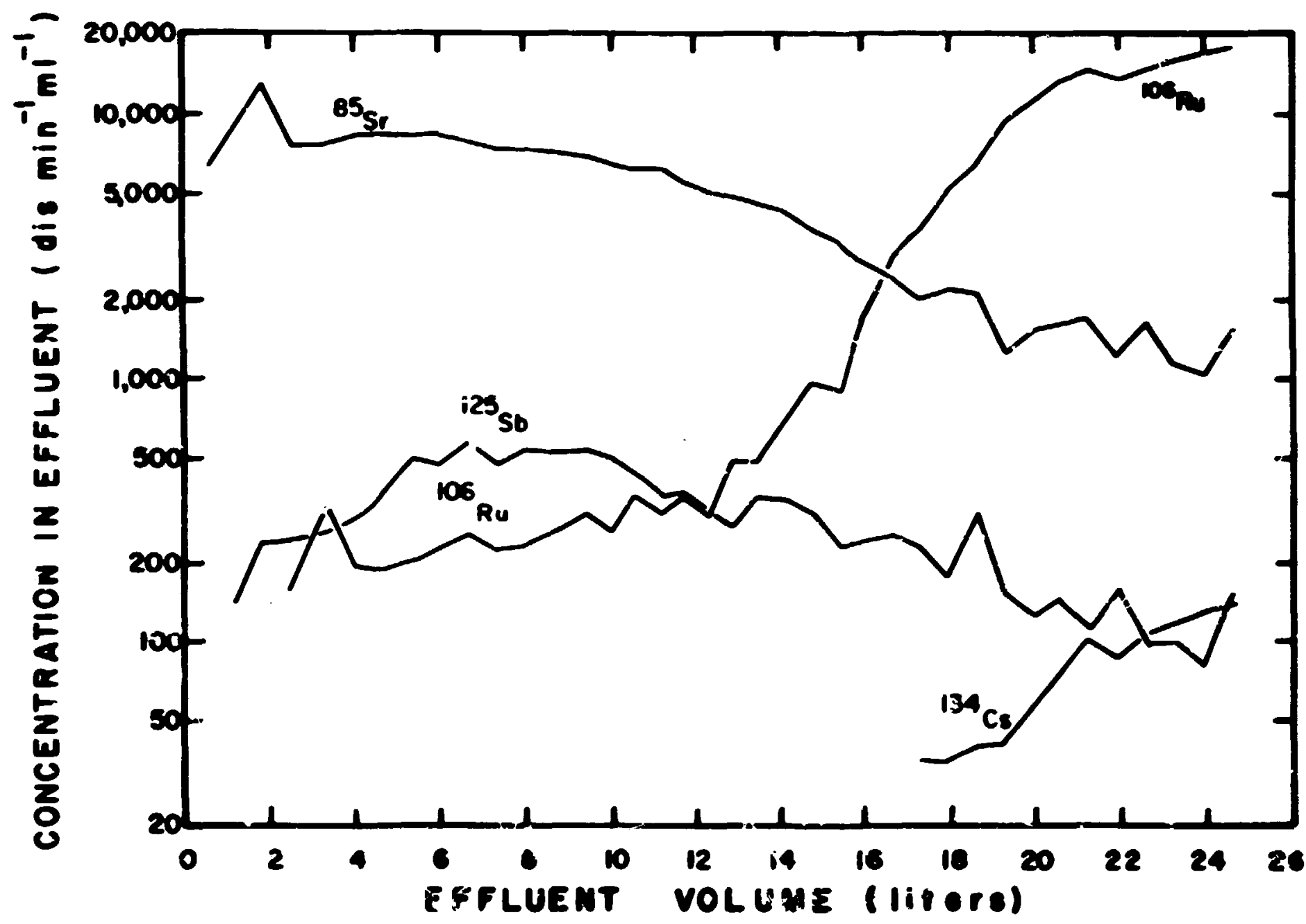

Fig. 19. Concentration of Radionuclides in the Colisun Effluent.

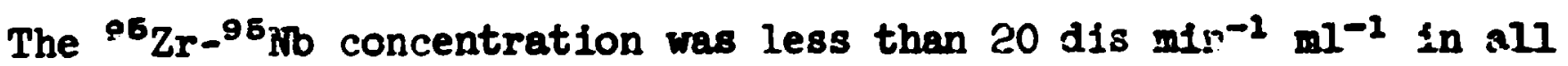
samples. 
range of 0.1 to $0.2 \mathrm{~g} / 1$ iter; the concentration in the strip product solution averaged about $22.6 \mathrm{~g} / \mathrm{liter}$ (Fig. 17). All of the samples of strip solution collected during the test had a gross gamma count that was less than $5 \%$ above baikground.

Electrowinning C:rcuit. - A total of $21.9 \mathrm{~g}$ of copper sas recovered from the strip solutions in the small electrolytic cell. The copper was deposited on three $1.5 \times 1.9 \times 0.01$ in. copper starting sheets spaced between four lead anodes of the same size. Two sets of cathudes were used during the run. The ceil was operated at a current density of about $7.5 \mathrm{~A} / \mathrm{ft}^{2}$, a cell potential of about $2 \mathrm{~V}$, and a cell temperature of $55^{\circ} \mathrm{C}$. The average copper concentration of the electrolyte decreased from 22.6 to $17.6 \mathrm{~g}$ / 1iter as the electrolyte passed through the cell (Fig. 17). At the some time, the average sulfuric acid concentration increased from $4.01 \mathrm{~N}$ to 4.17 N, ecial to 3.0 equivalent of acid for each equivalent of copper deposited. The acid generated during electrowisning, after exchange to the organic phase during stripping and to the leach liquor during extraction, was uitimately used to leach copper from the ore. After startup of the solvent extraction and electrowinning systems, no acid was adcied to the leaching system exr:ept for a small amount included in the acidified simulated well water that was added during the run to maintain the leach solution inventory.

We were not able to detect radioactiviti in the cathode copper products using our counting instrument. Two of the cathodes wert submitted to the ORIL Analytical Chemistry Division Por direct analysis in a new low-level counting facility. Trace concentrations of ${ }^{108} \mathrm{Ru}$, but no other radionuclides, were detected. The activities of copper products obtained early and late in the run, respectively, were measured to be $9 \times 10^{-6}$ and $2 \times 10^{-5} \mu \mathrm{Ci} / \mathrm{g}$. Analysis of the final electrolyte solution showed it to contain $0.005 \mu \mathrm{Cs}$ of ${ }^{96} \mathrm{Zr}-{ }^{95} \mathrm{Nb}$ and $0.01 \mu \mathrm{Cl}$ of ${ }^{100} \mathrm{Ru}$ per liter.

Kelex 100 Extractant. - Batch extractione were made with a 15 vol \% solutivi of Kelex 100-25 in Varscl frcm a sample of the lea $=$ h liquor that was in the system at the end of the test. Results of these extrections indicated trat the separation of copper from radioconteminants obtained with this reagent was approximately equivalent, to that obtained with LIX-64. 
The gross gamma count rate of the Kelex 100 copper extracts was oniy 2 to $6 \%$ higher than background.

Cementation Products. - For comparison, copper cenentation products were prepared from three samples of leach lsquor taken during the run. As expected, the cenent copper was appreciably contaninated with ${ }^{108} \mathrm{Ru}$. The amount of contamination increased from 0.02 to $1.0 \mu \mathrm{Cl}$ of ${ }^{106} \mathrm{Ru}$ per grem of copper as the ${ }^{108} \mathrm{Ru} / \mathrm{Cu}$ ratio in the solution increased during the run (Fig. 20). Nuch lower, although significant, anounts of ${ }^{298} \mathrm{Sb}$ also contaminated the cement copper products. Assuming a decontemination factor of 100 from ${ }^{106} \mathrm{Ru}$ during electrorefining of the cement copper, the activity of the final copper products would be one to three orders of magnitude higher tran the activity of proiucts that were obteined by the solvent extraction--electroutinning process.

\section{PROCESS ENALUATION}

In this ssction, both the cementation--copper casting--electrolytic purification flowsheet and the solvent extraction--electrowinning flo.rsheet are assessed frcm the standpoint of radionuclide control probleas. Considerations of potential hacards to operating personnel, suitability of the fincl copper product, and waste disposa: are included. Based on our test results, the presence of radionuclides in the processing plant should be a manageable problem. The radivactive contanination of the copper product produced by either process should be extremely low and not lazardous to the customer. The solvent extraction--electrowinning flowskeet appears to have important advantages oves the cemente.tion process flowsheet in each of the above categories and is the recomended process route.

\subsection{Leaching Circuit}

Assuming the amounts of redionuclides present in the systen to tes those s'ow: in Fig. 2, a rough estimate was made of the concentration of each that might be present in the circulating leach liquor (Table 7). The estimates of the fraction of each radionuclide that would be dissclved ane based on our leaching results and also general. Plowshare experience that 


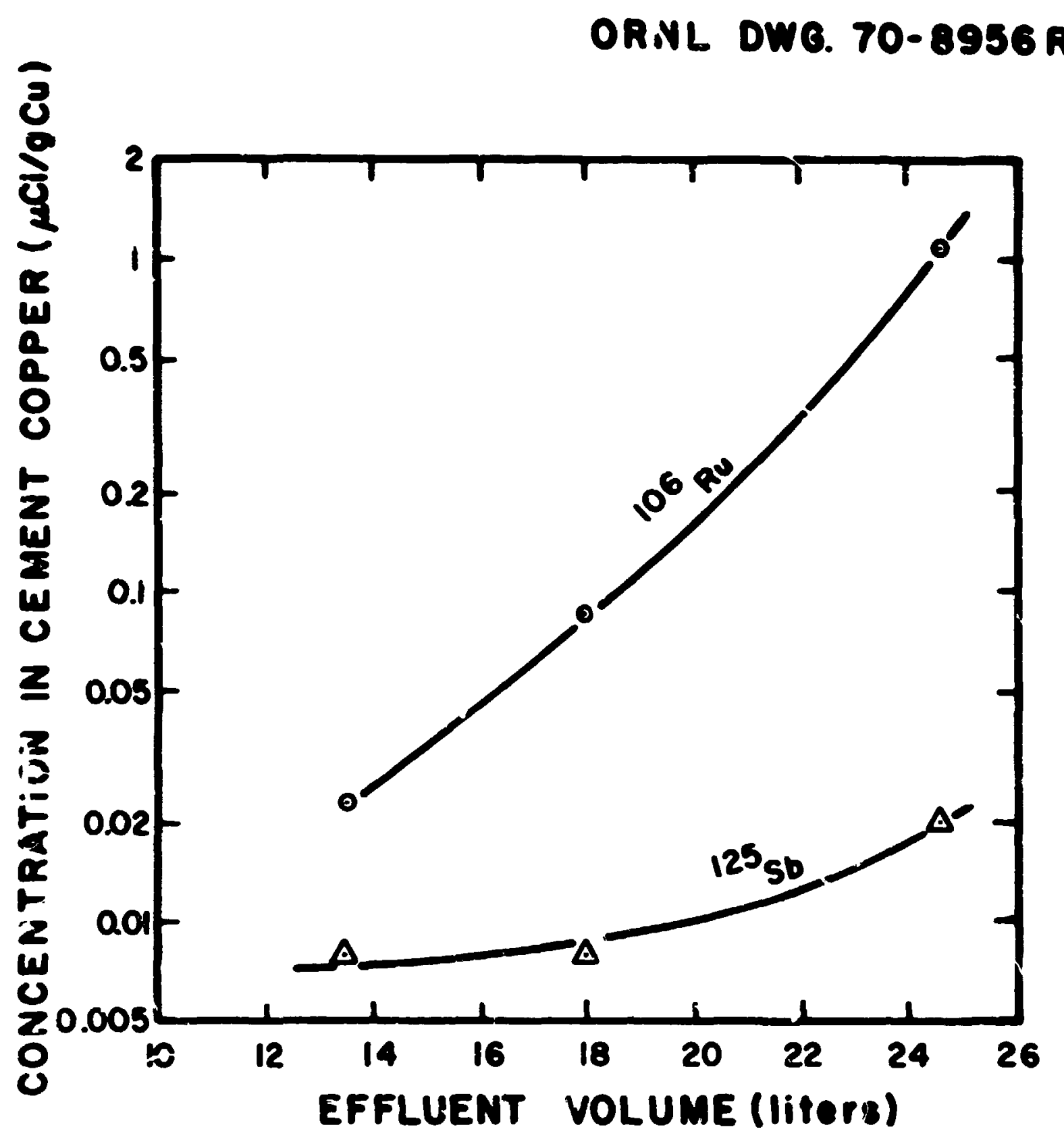

Fig. 20. Radiouctive Contemination of Cement Copper Products.

Procedure: 100-ml semples of column effluent vere stirred for $1 \mathrm{hr}$ with $0.35 \mathrm{~g}$ of sheet iron. The cement copper contained less than $0.002 \mu \mathrm{CI}$ of ${ }^{85} \mathrm{Sr},{ }^{95} \mathrm{Zr}-{ }^{98} \mathrm{Nb}$, or ${ }^{134} \mathrm{Cs}$ per gram. 
Table 7. Estinated Concentrations of Radionuclides in Circulating Leach Iiquor

Assuption: (1) to nifration of radiomaclides froi the chinoey.

(2) Inaching at 300 days after the shot.

(3) Uniforn distribution of the dissolved radionclides in 45 aillion gallons of circulating leach liquor.

\begin{tabular}{|c|c|c|}
\hline Isotope & $\begin{array}{c}\text { Percent of } \\
\text { Dissolution Assuec }\end{array}$ & $\begin{array}{l}\text { Concentrution in } \\
\text { Ieach Ifquor } \\
(\mu \mathrm{Cl} / \mathrm{il})\end{array}$ \\
\hline $98 \mathrm{zr}-98 \mathrm{mo}$ & $0.0 \overline{1}=1$ & $6 \times 10^{-6}-6 \times 10^{-4}$ \\
\hline $244 c$ & $0.01-1$ & $5 \times 10^{-6}-5 \times 10^{-4}$ \\
\hline${ }^{241} \mathrm{Ce}$ & $0.1-2$ & $2 \times 10^{-6}-5 \times 10^{-6}$ \\
\hline${ }^{306} \mathrm{Ru}$ & 0.1 & $6 \times 10^{-8}-9 \times 10^{-4}$ \\
\hline${ }^{303} \mathrm{Ru}$ & 0.1 & $4 \times 10^{-6}-7 \times 10^{-6}$ \\
\hline${ }^{137} \mathrm{Cs}$ & 0.1 & $7 \times 10^{-0}-1 \times 10^{-4}$ \\
\hline 12556 & 0.1 & $3 \times 10^{-6}-.5 \times 10^{-6}$ \\
\hline${ }^{90} \mathrm{Sr}$ & 0.5 & $1 \times 10^{-8}-3 . \times 10^{-4}$ \\
\hline${ }^{89} \mathrm{Sr}$ & 0.5 & $3 \times 10^{-8}-3 \times 10^{-4}$ \\
\hline $81 Y$ & $0.5-5$ & $5 \times 10^{-6}-5 \times 10^{-1}$ \\
\hline${ }^{147} \mathrm{Pm}$ & $0.001-0.1$ & $1 \times 10^{-7}-1 \times 10^{-6}$ \\
\hline${ }^{3} \mathrm{H}$ & 100 & 6 \\
\hline
\end{tabular}


onl; the fission product elements haring gaseous precursors and those forming volatile conpounds escape the precol apse cerity and conteninate the ore rubble; nost of the fission products are trapped efficiently in the meltad rock in inleachable form. consideraticn sias also given to the iact that a large portion of the soluble fraction of sone isotopes (e.g., $137 \mathrm{Cs}$ ) would be held firmly by the ore through fon exchange mechasisms (see Sect. 4.1). The calculaticns indicate that the expected activity levels should be sufficiently low to meke shielding of the process equipment (to prorent excessive exposire of personnel to radiation) unnecessary. With the exseption of tritiu, the potential hazards due to radioactivity appear to be of the same order as those in the irranium ore processing industry.

Tritium requires special consideration since it wild be completely leached and in volatile form; the principal tritiu hazara would be from tritiated water vapor, Since exposure to process vepors could be minimized by curering the processing tanks, the greatest potential for exposuce to tritiated water vapor wouid be in underground operations* such as the servicing of pups that force learh liquor to the surpace. Table 8 shows estimated tritiated water coicentrations in saturated air at $6 \mathrm{c}$ to $100 \%$, assuming that all of the water vapor in the air is derived from a leach liquor containing $6 \mu \mathrm{Cl}$ of tritiated sater por cubic centimeter. These concentrations exceed the maxirnm alloweo ${ }^{-11}$ for occupational workers (40-hr week) by factors of 16 to 55. This, of course, represents an extreme case since part of the water rapor in the air would cone from sources other than the leach liquor and the presence of operating personnel underground would be required imiermittently rather than contimuously; also, protective. clothing asd respirstors could be worn if necessary. Our leaching resultis (see Fig. 9) indicate that the tritiated water would be reared from the ore chimney at relatively high concentration in the initial portions of effluent and, therefore, uniform distribution of tritiated water in the liquor would occur only after the sclution was recycled nany times through

*Assuaing that leach liquor collects in a tunnel under tive formation as proposed for Project Sloop. ${ }^{1}$ Retrieval of the leach 11quar from the chimney by techniques other than tunneling isas been considered but nay not be feasib?e. 
Table 8. Estinated concentration of Mritiv in Saturatid Air

\begin{tabular}{|c|c|c|c|}
\hline \multirow{2}{*}{$\begin{array}{c}\text { Teuperature } \\
\left({ }^{\circ} F\right)\end{array}$} & \multirow{2}{*}{$\begin{array}{l}\text { Grans } \mathrm{H}_{2} \mathrm{O} \text { per } \\
\text { of Saturated } \mathrm{Al}\end{array}$} & \multicolumn{2}{|c|}{ Iritsu Concentration in Air } \\
\hline & & $\mu \mathrm{CI} / \mathrm{cc}^{\mathrm{a}}$ & Tines the IPC \\
\hline 60 & 13.3 & $8.0 \times 10^{-6}$ & 16 \\
\hline 70 & 18.4 & $12.0 \times 10^{-6}$ & 22 \\
\hline 90 & 34.2 & $20.5 \times 10^{-5}$ & 34 \\
\hline 100 & 45.7 & $27.4 \times 10^{-8}$ & 55 \\
\hline
\end{tabular}

Assuming saturation of ai from a solution containing $6 \mu \mathrm{CI}$ of tritiated water fer cc.

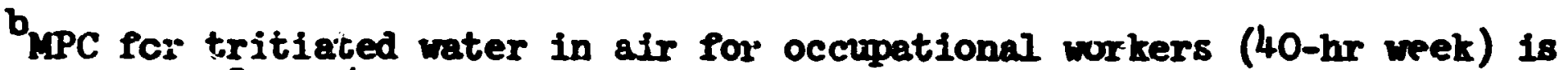
$0.5 \times 10^{-5} \mu \mathrm{Cl} / \mathrm{cc}$.

the colvan. The tritiu concentration in the circulating liquor omuld be significantly decreased by discarding the initing erfluert. Wheiber this would be worthwile, however, is questionable since it would camplicate waste disposal problems by increasing the waste solution volune. Also, process water is scarce in the vininity of the Safford ore deposits.

\subsection{Cementaition--Ancde Cast ing--Flectrolysis Flcirsheet}

Our tests have shown conclusively that significant contemination of the cement copper with ${ }^{106}$ Ru can be expected. The expected levei of contaminaticn, however, is uncertain prinarily because the fraction of the ${ }^{106}$ Ru that would be present in the chiney in a leachable forn is mot known. The colum leaching tests indicate that the copper/ $/{ }^{0}$ Ru ratio in the leach liquor would be considerebly higher in the initial siagas of the leaching cycle (high-pH effluent) than in the later stages; tims the ${ }^{108} \mathrm{Ru}$ contanination of the cenent copper should increase as the leaching proceers. This would be counteracted to sone extent by the $100 \mathrm{~s}$ of save leach solution frcm the systen and by decay of the ${ }^{106} \mathrm{Fu}$. Considering all

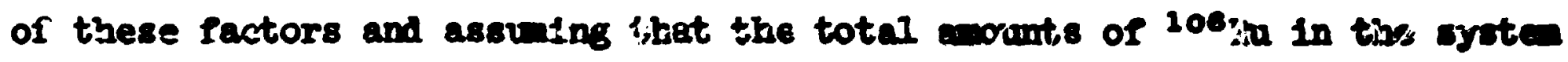
correspond to the use cf the particuiar device consicered in P18. 2,* we Doncerning effects of different derices, see refs. 12 and 13. 
estinate that the ${ }^{106} \mathrm{Ru}$ content of the cement copper wouid probably not exceed $0.05 \mu \mathrm{Ci}$ per grem at any time over the period of processing and, for most if the copper recovered, would be considerably less than this value. Although not high, this level of contamination dictates that care be taks $n$ in the desion and operation of the facility in order to minimize contact of the operating personnel with the ciment copper.

Areas for potential exposure to large amounts of radiocontaninated cement copper include the cemertation cones, mairitenance tunnels underneath the thickeners that are used to reduce the moisture content of the cement copper concentraies, and the filters. For an operation of this type, use of contimuous self-discharging filtere rather than, for exampie, fi]t.: presses would appear desirable in order to minimize exposure oi personnel. Good housekeeping should be practiced to avoid contamination of the processing area, and particular care should be taken to prevent the cement copper from spreading by drying and dusting.

Anode Casting. - The relting of the cement copper and the casting inte consumable anodes do not result in ang separation of ${ }^{108^{8} \mathrm{Ru}}$ from the coxper (see sect. 7.1). Although large amou cs of slightiy radioactive copper would be handled in these operations, this could be done remotely and the potential for significant radiation expssure would be small. The slag formed during the melting of the cement copper would be radioactive to the extent that it contains copper, and provision for its safe iisposal would be required.

Handling ana Storage of Anodes. - To obtain a rough idea of the maximum gama-radiation dose that operating peisonnel cocceivably could receive in handing the contaminated copper, calculations were made of the dose that, would be received in a room in which copper anodes were stored prior to electrolytic purificaticn. It was assumed that a mrker wuld be situatel in a corridor between copper anodes stacked to a height of $10 \mathrm{ft}$. The estimated grmua-radiation dose rates under these conditions are 0.2 ard $10 \mathrm{mR} / \mathrm{hr}$, respectipelv, for concentrations of ${ }^{106} \mathrm{Ru}$ in the copper of 0.001 and $0.05 \mathrm{\mu Ci} / \mathrm{g}$. The higher dose rate would require that the worker's time in this area be imited to about $10 \mathrm{hr} /$ week in order not to exceed acceptable dose Iimits. As mentioned above, a ${ }^{108} \mathrm{Ri}$ concentration of $0.05 \mu \mathrm{Cl} / \mathrm{s}$ is the highest level or contemination that we estimate will occur; the 
concentration should lisially be much lower than this value. Estimates of the beta-radiation dose to the hands that would occur on contact of bare hands with the copper anodes are 4 and $200 \mathrm{mR} / \mathrm{hr}$, respectively, for assumed ${ }^{106} \mathrm{Ru}$ concentrations in the copper of 0.001 and $0.05 \mu \mathrm{Ci} / \mathrm{g}$. Use of gloves, which would undoubtedly be required if hand contact with the anodes was necessary, would greatly reduce the dose rates. Based on these estimates, control if the gama or beta exposures uithil acceptable limits should not be difficult, provided proper wonitoring techniques and protective equipment are used.

Electrolytic Purification. - As described in Sect. 7.1, efficient separation of ${ }^{206} \mathrm{Ru}$ from the copper (decontanination factor of 50 to 100) is obtained during electrolytic purification. Host of the ${ }^{106} \mathrm{Ru}$ scevmulates in the cell electrolyte; the balance is fownd in the "anode mud" that accumulates at the bottom of the cell. Same provision for limiting ${ }^{106} \mathrm{Ru}$ sccumalation in the cell electrolyte by, for exaple, volatilizing it with ozonized air (sect. 7.3) would be required. The ${ }^{106} \mathrm{Ru}$ is easily trapped from the air with activated carbon. Suitable methods for handling and disposing of this carbon and of the radioactive anode sludge on its removal from the cell. would be needed. Sowever, it appears that providing for the protection of personnei in the electrolytic purification facility stould not be difficult.

Because of the expected efficient separation of copper from ${ }^{106} \mathrm{Ru}$ a'ring electralytic purification, the radioactivity of the final copper product should be very low ( $<0.001 \mu \mathrm{Cl}$ of ${ }^{108} \mathrm{Ru}$ per grom of copper) and not hazardous to the customer. This activity level, hovever, could possibly be high enough to make the copper unsuitable for certain specialized uses, for example, in radicuetric counting instruments, in the pho'ogra, hic industry, and for copper cooking ressels:

\subsection{Solvent Bxtraction--Electrowinning Flowsheet}

Solvent extraction provides a bighidy efficient separation of the copper from the radioactive conteninants in the leach liquor (see sect. 8). our tests indicate that the processing operations beyond the extraction contactors should be almost free of radicactivity. The radicactivity of 
the leach liquor (Table 7; would be too low to constitute a significant radiation hazard to operators of the solvent extrestion circuit. Provided the contactors were covered to minimize the release of tritium (as tritiated water vapor), tritium exposures to the operators also should be far below the allowable limit.

our test results indicate that the radioactivity of the final copper product recovered by solvent extraction and electrowinning would be negligible (essentially undetectable); therefore, marketing of the copper should not present a problem. The superior marketability of the product and the much simpler radiation control problems (at the processing site) that result from the use of solvent extraction as compared with the cementation process are very important advanteges. Thus solvent extraction is recanended.

\subsection{Waste Disposal}

If the solvent extraction--electrowinning flowsheet is used, the only apparent waste disposal problen would be final disposal of the leach solution. The volume of solution in the aboveground operations would not be large (a few million gallons at most) since alrost all of the leach solution is absorbed and this held by the ore. The solution in the processing tanks could be drained into the chimney at the conclusion of processing. The Safford ore body is dry and far above any knorn water tabie. ${ }^{1}$ Any solution that drained frum the chimney would be absurbed by the ore surrounding the chimney before it traveled a significant distance.

Use of the cemeatation--electrolytic purification flowsheet would yield addjtional was'ces. These include slag fram the anoce forming operation (Sect. 7.1), anode sludge from the electrolytic cells (isect. 7.1), and activated carbon used to trap ${ }^{108}$ Ru that is rolatilized from the cell electrolyte (Sect. 7.3). Since the only significant radiomalide in these wastes would be ${ }^{1 C 8} \mathrm{Ru}$, which has a relatively short half-life (1 year), sare disposal of these wastes should not be difficult. Prestauably, ground burial would be a suitable metbod of disposal. Alternatively, the material could be slurried in soluition and purped to the ore chinney. 


\section{ACRTONLEDGIEITS}

The authors wish to acknowiedge the contributions made to this work by F. J. Hurst, who participated in many of the tests and made the dose rate calculations. Valuable technical assistance was provided by D. E. Horner, W. B. Howerton, D. E. Spangler, J. S. Shreima, and J. R. Collins. We also wish to thank personnel at iawrence Radiation Laboratory, D. D. Rabb in particular, for supplying samples of radioactive test shot debris. Wet chemical analyses and some of the radicchemical anaijses were mede in the ORNL Analytical Chemistry Division.

\section{FEFEREITCES}

1. P. F. Zimer and M. A. Lekas (eds.), Sloop, PWB-1300 (June 1, 1967).

2. Mining Eng. 19, 60 (November 1967).

3. F. W. Stead, "Distribution in Groundwater of Radionuclides from Underground Fuclear Explosions," Third Plowshare Symposium, TID-7695 (Apri]. 1964).

4. G. H. Higzins, J. Geophys. Res. 64, 1509 (1359).

5. D. J. Crouse, W. D. Arnold, and F. J. Hurst, "Radioactive Contamination of Copper Produced using Fuclear Explosives," Proceedings of the AlS-AEC Symposium on Engineerins with Muclear Explosives, Las Vegas, Nevada, January 14-16, 1970, CORF-700101, Vol. 2, pp. 1569-88.

6. K. D. Arnold and D. J. Crouse, Chemical Applications of Fuclear Explosions (CANE): Progress Reports for

(a) October 1 to December 31, 1965, ORRL-TM-1394, pp. 3-15.

(b) January 1 to March 31, 1966, ORHL-TM-1496, pp. 4-13.

(c) April 1 to June 30, 1966, ORII-TM-1582, pp. 5-12.

(d) July 1 to Septenber 30, 1966, ORLL-TM-1688, pp. 4-14.

(e) October 1 to December 31, 1966, ORII-TMI-1775, pp. 2-9.

(f) January 1 to March 31, 1967, ORLL-TM-1886. pp. 4-10.

(g) April i to June 30, 1957, ORIL-TM-1932, pp. 4-8.

(b) July 1 to Septenber 30, 1967, ORIL-TM-2062, pp. 4-10.

(i) October 1 to Deceuber 31,1967 , ORIL-TM-2119, pp. 4-7.

(j) January i to March 31, 1968, ORII-TM-2198, pp. 4-5.

(k) April 1 to June 30, 1968, 0Rin-Ty-2298, pp. 4-3.

(1) October 1 to Decener 31, 1968, ORII-TM-2502, pp. 4-5.

(m) Jamuary 1 to March 31. 1969, ORII-MM-2561, pp. 4-5.

(i) April I to June 30, 1969, ORII-MM-2689, pp. 4-10. 
(o) July 1 to September 30, 1969, ORNL-TM-25?6, pp. 4-7.

(p) Jctoker 1 to December 31, 1969, ORNL-TM-2888, pp. 4-5.

(q) January 1 to March 31, i970, ORNL-TM-303', pp. 4-11.

(r) April 1 to June 30, 1970, ORNL-TM-31i6, pp. 5-18.

7. J. A. Miskel, "Characterist,ics of Radioactivity Produced by Nuclear Explosives," Third Plnwshare Symposium, TID-769; (April 1964).

8. D. D. Rabb, Lawrence Radietion Laboratory, personal communication.

9. H. J. McGarr, N. H. Berlin, and W. F. A. Stolk, Eng. Mining J. 170(12), 66 (Deccmber 1969).

10. H. J. McGarr, Eng. Mining J. 171(10), 79 (October 1970).

i1. Coue or Federal Regulations, Title 10, Part 20, Ferera: Register (March 21, 1968).

12. R. M. Lessler, "Reduction of Radioactivity Produced by Muclear Explosives," Proceedings of the ANS-AEC Symposium on Engineering with Nuclear Explosives, Las Vegas, Nevada, January 14-10., 1970, CONF-700101, Vol. 2, pp. 1563-68.

13. A Feasibility Study of a Plowshare Geothermal Power Plant, April 1971, by the U.S. Atomic Energy Commission (AEC) and American Cii ihale Corporation (AOS), pp. 6.1-6.10. 